\title{
Review of Quantitative Microbial Risk Assessment in Poultry Meat: The Central Position of Consumer Behavior
}

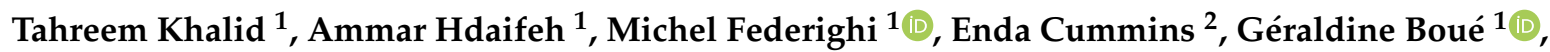 \\ Sandrine Guillou ${ }^{1, *(D)}$ and Vincent Tesson ${ }^{1}$ (D) \\ 1 SECALIM, INRAE, Oniris, 44307 Nantes, France; tahreem.khalid@oniris-nantes.fr (T.K.); \\ ammar.hdaifeh@oniris-nantes.fr (A.H.); michel.federighi@oniris-nantes.fr (M.F.); \\ geraldine.boue@oniris-nantes.fr (G.B.); vincent.tesson@inrae.fr (V.T.) \\ 2 Biosystems and Food Engineering, University College Dublin, Belfield, Dublin 4, Ireland; \\ enda.cummins@ucd.ie \\ * Correspondence: sandrine.guillou@oniris-nantes.fr
}

Received: 23 September 2020; Accepted: 12 November 2020; Published: 13 November 2020

\begin{abstract}
Food of animal origin, especially meat products, represent the main vehicle of foodborne pathogens and so are implicated in foodborne outbreaks. Poultry meat is a widely consumed food in various forms, but it is also a reservoir of thermotolerant Campylobacter and Salmonella bacterial species. To assess human health risks associated with pathogenic bacteria in poultry meat, the use of quantitative microbial risk assessment (QMRA) has increased over the years as it is recognized to address complex food safety issues and is recommended by health authorities. The present project reviewed poultry meat QMRA, identified key steps of the farm-to-fork chain with significant impacts on food safety, highlighted current knowledge gaps, and provided risk mitigation advices. A PRISMA (Preferred Reporting Items for Systematic Reviews and Meta-Analyses)-based systematic analysis was carried out and enabled the collection of 4056 studies including 43 QMRA kept for analysis after screening. The latter emphasized Campylobacter spp. and Salmonella spp. contaminations during the consumer stage as the main concern. The role of consumer handling on cross-contamination and undercooking events were of major concern. Thus, proper hygiene and safety practices by consumers have been suggested as the main intervention and would need to be followed with regular surveys to assess behavior changes and reduce knowledge gaps.
\end{abstract}

Keywords: food safety; QMRA; meat chain; poultry; food preparation; consumer behavior

\section{Introduction}

According to the World Health Organization (WHO) in 2010, around 600 million cases of foodborne illness and 420,000 deaths were reported due to the consumption of food contaminated by enteric pathogens worldwide [1]. In the EU, there were around 5146 foodborne outbreaks in 2018, with meat and related products a major source of infection, responsible for $17.9 \%$ of strong-evidence foodborne outbreaks in 2018 [2]. The most common agent detected was Salmonella spp. with Salmonella ser. Enteritidis, which caused one out of three outbreaks. It was followed by bacterial toxins then Campylobacter spp. (12.7\% and $10.2 \%$ of reported outbreaks, respectively) [2]. Salmonella spp. in eggs and meat and meat products were the top ranked hazard/food pairs [2]. The presence of foodborne microbial pathogens along the poultry meat chain is one of the major public health concerns. Poultry is often known as a reservoir of human enteric pathogens such as thermotolerant Campylobacter spp. and Salmonella spp., mostly present in the intestinal tract of birds, which often appear asymptomatic [3]. In 2017, the EU flock prevalence of target Salmonella spp. serovars in breeding hens, laying hens, 
broilers, and fattening turkeys slightly decreased or remained stable compared to 2017 [2]. In a report of European Center for Diseases Control (ECDC) and European Food Safety Authority (EFSA), campylobacteriosis was shown to be the most commonly reported zoonosis and the EU trend for confirmed human cases has increased since 2008 and remained stable during 2014-2018 [2]. Human campylobacteriosis is most commonly associated with the consumption of poultry, specifically fresh, portioned, or whole broiler meat products [4-6]. Moreover, broiler is highly consumed worldwide, estimated at $13.9 \mathrm{~kg}$ per capita in 2015-2017 and expected to increase up to $14.6 \mathrm{~kg}$ per capita up to 2027 [7]. In the EU from 2015 to 2017, the average poultry meat consumption was higher with $23.74 \mathrm{~kg}$ per capita and an increase up to $24.9 \mathrm{~kg}$ per capita is expected by 2027 [7]. In comparison, the French are large consumers with approximately $26.3 \mathrm{~kg}$ per capita of (90\% broiler meat) consumed in 2014 [8]. Poultry meat is purchased in the form of whole carcasses, cutting parts, and other elaborated products, which accounts for $25 \%, 44 \%$, and $31 \%$, respectively [8].

To assess the risk associated with poultry consumption and evaluate risk reduction measures, Quantitative Microbial Risk Assessment (QMRA) is used as a structured approach that enables the estimation of the probability of illness to which people may be exposed. It consists of determining the level of contamination by human/animal related pathogens, which may represent a risk to human health [9]. QMRA consists of four steps: hazard identification, hazard characterization, exposure assessment, and risk characterization [10]. The poultry meat chain comprises several steps starting from the breeder to the consumption. There are several possible routes of contamination along the farm-to-fork chain of poultry meat products, from the colonization of the chick gut by microbial pathogens at the farm level to their spread and growth during the slaughter process, the retail and preparation steps, and till consumption. Thus, QMRA can be useful in providing a food safety approach to minimize the risk of pathogen exposure and potential resulting health issues.

In the present paper, a critical analysis of existing QMRA studies related to poultry meat products in the farm-to-fork chain was performed. The objective of this analysis was to pinpoint knowledge gaps and issues within the critical steps of the poultry chain, especially the consumer step, to identify how an improved QMRA may refine intervention strategies.

\section{Materials and Methods}

The scientific papers were collected through exhaustive literature search following the PRISMA guidelines [11,12] on Web of Science (WoS) and Scopus. For each database, the following search queries were used:

- WoS: TITLE: (poultry OR chicken* OR broiler* OR poulet* OR volaille* OR duck* OR geese* OR turkey* OR dinde* OR oie* OR canard*) AND TITLE: (risk* OR risque* OR "risk assessment" OR aqr OR QMRA OR exposure OR "modelling")

- Scopus: (TITLE (poultry OR chicken* OR broiler* OR poulet* OR volaille* OR duck* OR geese* OR turkey* OR dinde* OR oie* OR canard*) AND TITLE (risk* OR risque* OR "risk assessment" OR aqr OR qmra OR exposure OR modeling OR modelling).

The search was done on each database considering their respective starting year-1956 for Web of Science, 1788 for Scopus-to the date of the 11 February 2020. A total of 4565 articles (2242 from Web of Science and 2323 from Scopus) were collected, and 32 papers from the grey literature (mostly reports from European health agencies and the WHO) were added. Then, articles were screened that involved the removal of duplicates and scrutiny of titles and abstracts. Records were considered eligible after thorough inspection of full texts. During the whole selection process, only articles that met potential inclusion criteria were included: studies related to poultry QMRA, predictive modeling, risk factors, and prevalence of poultry pathogens. The studies were included without geographical discrimination. Studies that did not comply with the inclusion criteria were rejected. 


\section{Results}

\subsection{Summary of Collected Papers}

A total of 139 studies were collected after screening through the PRISMA method in which 43 studies specifically concerned poultry QMRA [8,13-54], along with 96 additional studies on specific interests (Figure 1). These latter additional studies covered the following topics:

- $\quad$ Predictive microbiology including modeling of microbial growth, inactivation. and survival along the meat chain [55-76];

- Estimation of the prevalence of contamination at several steps [77-107];

- Identification of risk factors along the meat chain causing microbial contamination or growth [77,78,80-85,87,89-93,97,98,100-147];

- Modeling cross-contamination events [74,148,149]; and

- $\quad$ Modeling heat and cooling processes for poultry products [76,150,151].

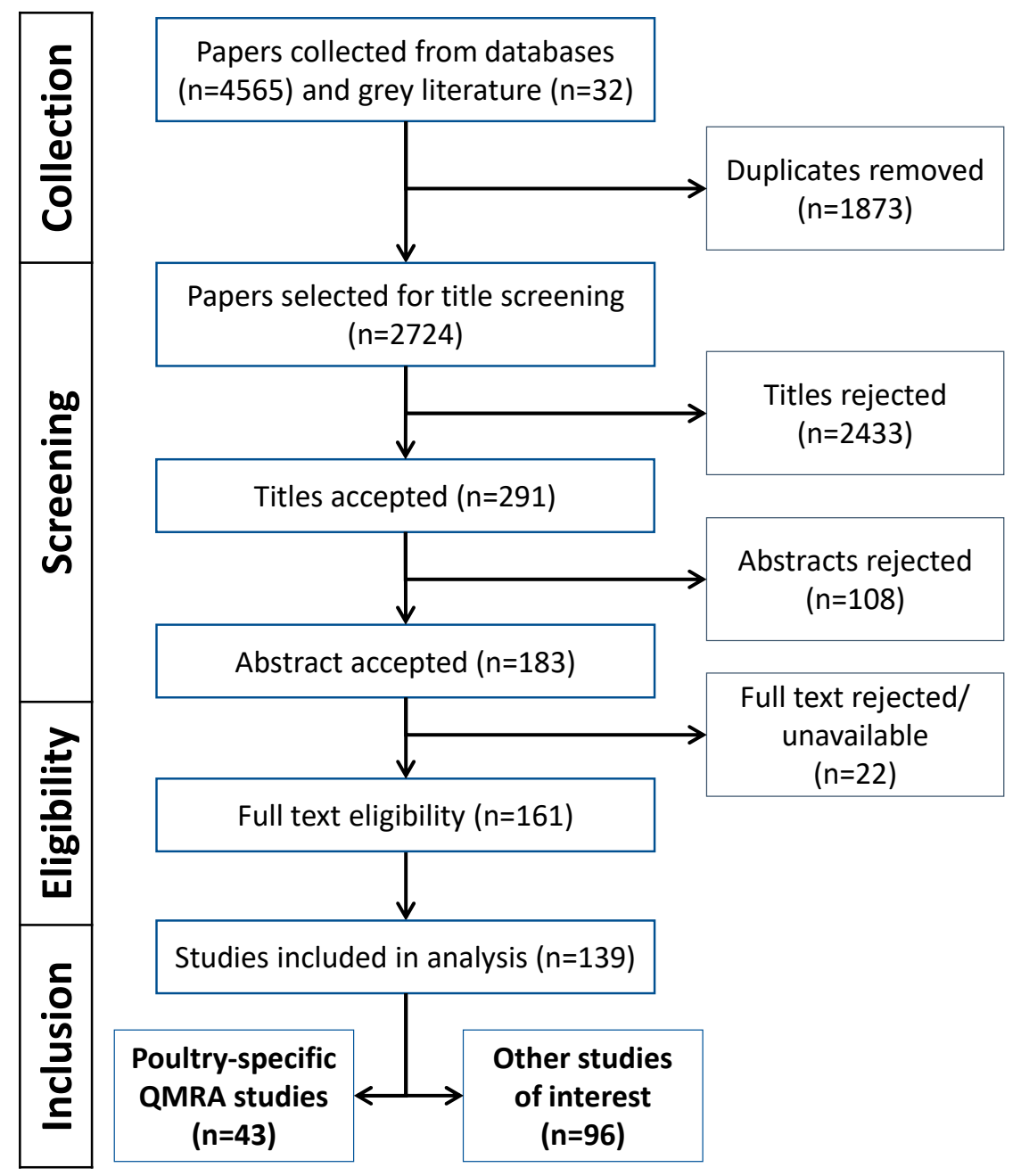

Figure 1. Flow chart of the data search process and results, based on the PRISMA diagram [11,12].

QMRA studies included in this systematic review were from Europe (23/43), covering France, the Netherlands, Germany, Finland, Sweden, Denmark, Italy, Belgium, the United Kingdom, Sweden, Denmark, Finland, Norway and Iceland); North America (10/43), covering the USA and Canada; South America (2/43), covering Chile and Argentina; Asia (5/43), covering China, South Korea, and Thailand; and one country from Africa (i.e., Senegal) (Table 1). 
Table 1. Summary of collected poultry meat QMRA papers.

\begin{tabular}{|c|c|c|c|c|c|}
\hline Pathogen & Product & Location Date & Population & Objective & Refs \\
\hline \multirow{13}{*}{ Salmonella spp. } & \multirow{4}{*}{ Broiler } & Canada 2012 & All & $\begin{array}{l}\text { Meta-analysis for evaluation of } \\
\text { farm-to-processing interventions }\end{array}$ & [13] \\
\hline & & Canada 2020 & All & $\begin{array}{c}\text { Risk assessment, evaluation of mitigation } \\
\text { strategies }\end{array}$ & [14] \\
\hline & & Finland 2005 & All & $\begin{array}{l}\text { Effect of two interventions of Finnish control } \\
\text { program }\end{array}$ & [18] \\
\hline & & China 2017 & All & $\begin{array}{l}\text { Risk assessment of home-prepared chicken } \\
\text { meals }\end{array}$ & [19] \\
\hline & \multirow[t]{2}{*}{ Chicken } & USA 1998 & All & $\begin{array}{c}\text { Determination of Salmonella spp. } \\
\text { contamination levels on chickens at } \\
\text { processing plant exit and risks for consumers }\end{array}$ & [15] \\
\hline & & USA 2004 & All & $\begin{array}{l}\text { Risk assessment based on updated model } \\
\text { from [15] }\end{array}$ & [16] \\
\hline & \multirow{3}{*}{ Chicken meat } & USA 2017 & All & $\begin{array}{c}\text { Risk assessment following flow pack } \\
\text { wrapping of whole chicken and temperature } \\
\text { abuse }\end{array}$ & [17] \\
\hline & & Canada 2013 & All & $\begin{array}{l}\begin{array}{l}\text { Risk assessment of home-prepared chicken } \\
\text { meals }\end{array}\end{array}$ & [20] \\
\hline & & The Netherlands 2007 & All & $\begin{array}{c}\text { Risk assessment, impact of contamination } \\
\text { level at retail }\end{array}$ & [21] \\
\hline & \multirow{4}{*}{ Meat preparation ${ }^{1}$} & France 2003 & All & $\begin{array}{l}\text { Risk assessment at catering establishments } \\
\text { level }\end{array}$ & [22] \\
\hline & & South Korea 2018 & All & $\begin{array}{l}\text { Risk assessment, impact of contamination } \\
\text { concentration at retail }\end{array}$ & [23] \\
\hline & & USA 2019 & All & $\begin{array}{l}\text { Risk assessment for developing a risk } \\
\text { management framework }\end{array}$ & [24] \\
\hline & & USA 2019 & All & $\begin{array}{l}\text { Process risk model for ground chicken, } \\
\text { partly based on [17] }\end{array}$ & [25] \\
\hline
\end{tabular}


Table 1. Cont.

\begin{tabular}{|c|c|c|c|c|c|}
\hline Pathogen & Product & Location Date & Population & Objective & Refs \\
\hline \multirow{14}{*}{$\begin{array}{l}\text { Thermotolerant } \\
\text { Campylobacter spp. }\end{array}$} & \multirow{10}{*}{ Broiler } & UK 2001 & All & $\begin{array}{l}\text { Risk assessment for broilers } \\
\text { at point of slaughter }\end{array}$ & [26] \\
\hline & & UK 2017 & All & $\begin{array}{c}\text { Assessment of mitigation interventions at } \\
\text { farm level }\end{array}$ & [27] \\
\hline & & EU 2011 & All & $\begin{array}{l}\text { Impact of mitigation interventions at } \\
\text { primary production and slaughter }\end{array}$ & {$[28]$} \\
\hline & & EU 2013 & All & $\begin{array}{l}\text { Impact of farm to fork interventions on } \\
\text { human campylobacteriosis incidence }\end{array}$ & [29] \\
\hline & & USA 2019 & All & Assessment of processing interventions & [30] \\
\hline & & The Netherlands 2005 & All & $\begin{array}{l}\text { Risk assessment, poultry processing model } \\
\text { basis }\end{array}$ & {$[31]$} \\
\hline & & Sweden 2008 & All & $\begin{array}{l}\text { Evaluation of mitigation strategies and } \\
\text { frequency of cross contamination due to } \\
\text { consumer mishandling }\end{array}$ & [37] \\
\hline & & United Nations 2009 & All & $\begin{array}{l}\text { Risk assessment based on extensive review } \\
\text { of knowledge }\end{array}$ & {$[40,41]$} \\
\hline & & Nordic countries 2013 & $\begin{array}{l}\text { Young, adult, } \\
\text { males }\end{array}$ & $\begin{array}{l}\text { Establishment of risk-based microbiological } \\
\text { criteria }\end{array}$ & [42] \\
\hline & & France 2018 & All & $\begin{array}{l}\text { Risk - benefit assessment of mitigation } \\
\text { interventions }\end{array}$ & [8] \\
\hline & \multirow{2}{*}{ Chicken } & Denmark 2003 & All & $\begin{array}{c}\text { Risk assessment, impact of mitigation } \\
\text { strategies }\end{array}$ & [39] \\
\hline & & China 2013 & All & Prevalence estimation and risk assessment & [36] \\
\hline & \multirow{2}{*}{ Poultry } & Thailand 2011 & All & $\begin{array}{l}\text { Exposure assessment and processing risk } \\
\text { factors identification }\end{array}$ & {$[38]$} \\
\hline & & China 2018 & All & $\begin{array}{l}\text { Risk assessment based on } \\
\text { poultry-processing model }\end{array}$ & [35] \\
\hline
\end{tabular}


Table 1. Cont.

\begin{tabular}{|c|c|c|c|c|c|}
\hline Pathogen & Product & Location Date & Population & Objective & Refs \\
\hline \multirow{9}{*}{$\begin{array}{l}\text { Thermotolerant } \\
\text { Campylobacter spp. }\end{array}$} & \multirow{8}{*}{ Chicken meat } & Denmark 2012 & All & $\begin{array}{c}\begin{array}{c}\text { Evaluation of control strategy for imported, } \\
\text { meat }\end{array}\end{array}$ & [43] \\
\hline & & Denmark 2013 & All & $\begin{array}{l}\text { Risks associated with thermotolerant } \\
\text { Campylobacter, based on [49] }\end{array}$ & {$[44]$} \\
\hline & & Denmark 2013 & All & $\begin{array}{l}\text { Risk assessment for individual batches of } \\
\text { fresh poultry meat }\end{array}$ & [45] \\
\hline & & Netherland 2007 & All & Tool for mitigation measures assessment & [32-34] \\
\hline & & Germany 2008 & All & $\begin{array}{l}\text { Risk assessment of frozen/fresh chicken legs } \\
\text { and breasts, for household consumption }\end{array}$ & [46] \\
\hline & & Italy 2008 & All & $\begin{array}{l}\text { Risk assessment of human } \\
\text { campylobacteriosis due to cross } \\
\text { contamination }\end{array}$ & [47] \\
\hline & & Argentina 2013 & All & $\begin{array}{l}\text { Risk assessment for cross-contaminated } \\
\text { salad }\end{array}$ & [48] \\
\hline & & EU 2012 & All & $\begin{array}{l}\text { Impact of microbial criteria at the end of } \\
\text { industrial processing }\end{array}$ & [49] \\
\hline & Meat preparation ${ }^{1}$ & Belgium 2006 & All & $\begin{array}{l}\text { Support for definition of risk-based } \\
\text { microbial criteria }\end{array}$ & [50] \\
\hline $\begin{array}{l}\text { Campylobacter spp. and } \\
\text { Salmonella spp. }\end{array}$ & Chicken meat & Senegal 2012 & All & $\begin{array}{l}\text { Risk assessment considering from market to } \\
\text { consumption }\end{array}$ & [51] \\
\hline \multirow{2}{*}{ Listeria monocytogenes } & Poultry & Chile 2015 & All & $\begin{array}{l}\text { Risk assessment for both poultry and beef } \\
\text { meat }\end{array}$ & [52] \\
\hline & Broiler legs & Finland 2008 & All & Plant-level risk assessment & {$[53]$} \\
\hline Clostridium perfringens & Meat preparation ${ }^{1}$ & USA 2009 & All & $\begin{array}{l}\text { Effect of maximum allowed growth during } \\
\text { stabilization of ready-to-eat foods }\end{array}$ & {$[54]$} \\
\hline
\end{tabular}

1: "Meat preparation" referred to portioned, cut, or minced meat to which spices or other ingredients might have also been added to improve sensorial properties or texture. Sausages and hamburgers of raw minced poultry meat were included as meat preparation products. 


\subsection{Poultry Farm-to-Fork Chain}

A graphical representation of the farm-to-fork chain for poultry meat products considered by QMRA studies in this review is shown in Figure 2. This was shown to be common to all geographical regions considered in the collected studies. The farm-to-fork chain of poultry consists of some key stages: farm, slaughtering and processing, retail, and consumer. A short description of each step is given below.

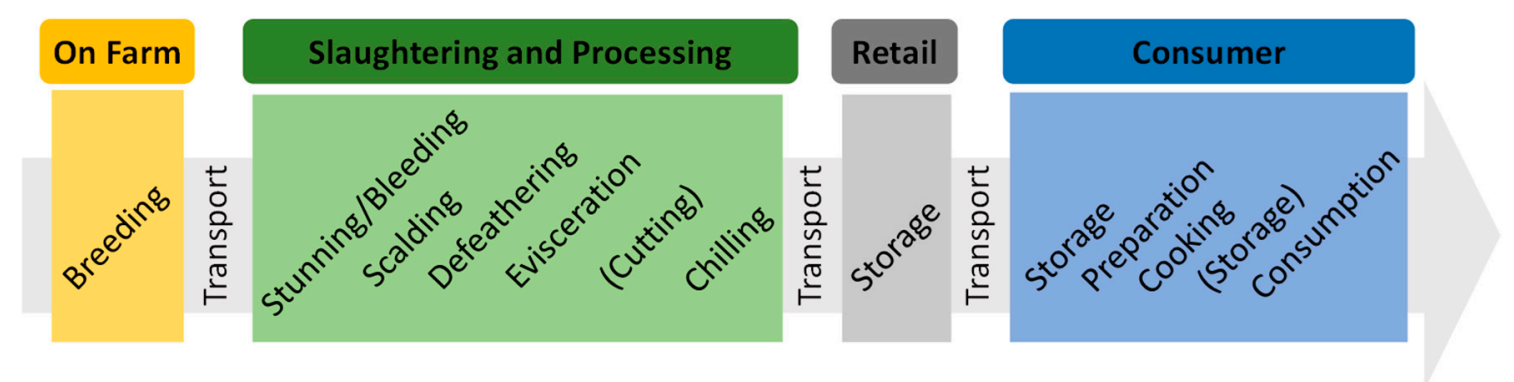

Figure 2. Farm-to-fork chain for poultry meat as commonly considered by quantitative microbial risk assessment (QMRA) studies. Steps within brackets are optional but considered by some authors.

\subsubsection{Farm}

In poultry production, one-day-old chicks are transported from the hatchery to different farms for rearing purposes. This production is accomplished through different farming systems that vary in genotype, housing environments, and rearing methods [8]. In the EU, these systems include extensive indoor, free range, organic, and intensive farming systems [152].

\subsubsection{Slaughtering and Processing}

Poultry are transported from farms to slaughterhouses. Stages in poultry slaughtering consist of stunning, bleeding, defeathering, evisceration, and processing, which includes the chilling of whole carcasses or further processing like poultry portioning/cutting [8,26,34]. Before transportation to slaughterhouses, chickens are not fed for less than $12 \mathrm{~h}$ to minimize the risk of contamination due to fecal leakage during transport [8]. This way, by emptying the bowels, it helps to reduce the skin contamination level by less than $5 \%$ after evisceration [8].

\subsubsection{Retail}

After the processing stage, poultry in different meat cuts or as whole carcasses are transported to retail stores/outlets and kept under $4{ }^{\circ} \mathrm{C}$. In addition, cuts and carcasses can be packaged using specific measures like modified atmosphere or specific packaging materials to ensure better and longer storage of the product.

\subsubsection{Consumer}

The consumer stage involves the transport of whole chicken carcasses or poultry products from retail store/outlets to home places. Products are either cooked immediately or after storage in refrigerators.

\subsection{Pathogens Included in the Review of Quantitative Microbial Risk Assessment (QMRA) Studies}

As illustrated in Figure 3, most of the collected papers dealt with thermotolerant Campylobacter spp. (61\% 27/43), followed by Salmonella spp. (32\%, 14/43). Other studies concerned Listeria monocytogenes and Clostridium perfringens ( $2 / 43$ and $1 / 43$, respectively). 


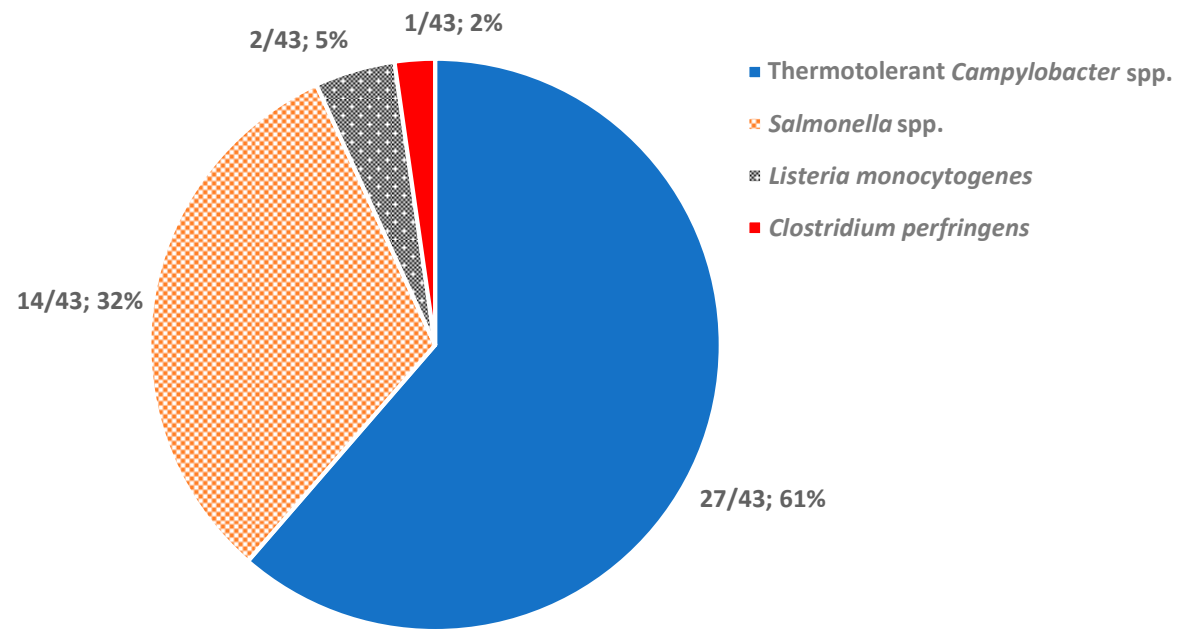

Figure 3. Pathogens included in review of QMRA studies. One paper [51] included QMRAs for both Salmonella spp. and thermotolerant Campylobacter spp., so it was counted twice.

Regardless of the region, Salmonella spp. and thermotolerant Campylobacter species were the two first-ranked pathogens in almost all cases [1]. Salmonella spp. is acknowledged as the etiologic agent of the human salmonellosis disease while thermotolerant Campylobacter species-with Campylobacter jejuni ranked first followed by coli, lari, and upsaliensis - are the cause of human campylobacteriosis. Both diseases cause gastroenteritis symptoms (e.g., diarrhea, fever, vomiting, and abdominal cramps) for several days. Nevertheless, salmonellosis can lead to outcomes like sepsis and typhoid fever, in the case of lymphatic system invasion or inflammatory bowel disease. Considering campylobacteriosis, diarrhea can evolve into dysentery while the disease itself can lead to sepsis, but also asthenia, arthritis, endocarditis, or even nerve damage, leading to a Guillain-Barré syndrome outcome.

The two last ranked pathogens were Listeria monocytogenes and Clostridium perfringens. Listeriosis disease, associated with Listeria monocytogenes infection, is a disease known to mainly affect sensitive populations (newborn, pregnant women, immunocompromised, and elderly people) with a very high severity. Clostridium perfringens is mostly associated with self-limiting diarrheas caused by thermoresistant enterotoxin A.

\subsection{Parts of the Farm-to-Fork Chain Considered in QMRA Studies}

Steps of the farm-to-fork chain considered in collected QMRA studies are identified in Table 2.

Table 2. Identification of steps of the farm-to-fork chain considered in poultry QMRA papers.

\begin{tabular}{|c|c|c|c|c|c|}
\hline Pathogen & Reference & Farm (12) & Slaughter (20) & Retail (25) & Consumer (33) \\
\hline \multirow{13}{*}{ Salmonella spp. } & Bucher et al., 2012 [13] & $\checkmark$ & $\checkmark$ & & \\
\hline & Collineau et al., 2020 [14] & $\checkmark$ & $\checkmark$ & $\checkmark$ & $\checkmark$ \\
\hline & Oscar 1998 [15] & & $\checkmark$ & $\checkmark$ & $\checkmark$ \\
\hline & Oscar 2004 [16] & & & $\checkmark$ & $\checkmark$ \\
\hline & Oscar 2017 [17] & & & $\checkmark$ & $\checkmark$ \\
\hline & Maijala et al., 2005 [18] & $\checkmark$ & $\checkmark$ & $\checkmark$ & $\checkmark$ \\
\hline & Zhu et al., 2017 [19] & & & $\checkmark$ & $\checkmark$ \\
\hline & Smadi \& Sargeant 2013 [20] & & & $\checkmark$ & $\checkmark$ \\
\hline & Straver et al., 2007 [21] & & & $\checkmark$ & $\checkmark$ \\
\hline & Bemrah et al., 2003 [22] & & & $\checkmark$ & $\checkmark$ \\
\hline & Jeong et al., 2018 [23] & & & $\checkmark$ & $\checkmark$ \\
\hline & Sampedro et al., 2019 [24] & & & & $\checkmark$ \\
\hline & Oscar et al., 2019 [25] & & & & $\checkmark$ \\
\hline
\end{tabular}


Table 2. Cont.

\begin{tabular}{|c|c|c|c|c|c|}
\hline Pathogen & Reference & Farm (12) & Slaughter (20) & Retail (25) & Consumer (33) \\
\hline \multirow{23}{*}{$\begin{array}{l}\text { Thermotolerant } \\
\text { Campylobacter spp. }\end{array}$} & Hartnett et al., 2001 [26] & $\checkmark$ & $\checkmark$ & & \\
\hline & Crotta et al., 2017 [27] & $\checkmark$ & $\checkmark$ & & \\
\hline & EFSA 2011 [28] & $\checkmark$ & $\checkmark$ & $\checkmark$ & $\checkmark$ \\
\hline & Romero-Barrios et al., 2013 [29] & $\checkmark$ & $\checkmark$ & & $\checkmark$ \\
\hline & Dogan et al., 2019 [30] & $\checkmark$ & $\checkmark$ & 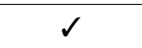 & $\checkmark$ \\
\hline & Nauta et al., 2005 [31] & & $\checkmark$ & & \\
\hline & $\begin{array}{l}\text { Katsma et al.; Havelaar et al.; } \\
\text { Nauta et al., } 2007 \text { [32-34] }\end{array}$ & $\checkmark$ & $\checkmark$ & $\checkmark$ & $\checkmark$ \\
\hline & Huang et al., 2018 [35] & & $\checkmark$ & & \\
\hline & Lindqvist and Lindblad 2008 [37] & & $\checkmark$ & $\checkmark$ & $\checkmark$ \\
\hline & Osiriphun et al., 2011 [38] & & $\checkmark$ & & \\
\hline & Rosenquist et al., 2003 [39] & & $\checkmark$ & $\checkmark$ & $\checkmark$ \\
\hline & Wang, Guo \& Li, 2013 [36] & $\checkmark$ & $\checkmark$ & & $\checkmark$ \\
\hline & FAO, WHO $2009[40,41]$ & $\checkmark$ & $\checkmark$ & & $\checkmark$ \\
\hline & Nauta et al., 2013 [42] & & & & $\checkmark$ \\
\hline & Anses 2018 [8] & $\checkmark$ & $\checkmark$ & $\checkmark$ & $\checkmark$ \\
\hline & Boysen 2012 [43] & & $\checkmark$ & 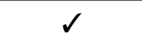 & \\
\hline & Boysen et al., 2013 [44] & & & & $\checkmark$ \\
\hline & Christensen et al., 2013 [45] & & & 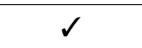 & $\checkmark$ \\
\hline & Brynestad et al., 2008 [46] & & & $\checkmark$ & $\checkmark$ \\
\hline & Calistri \& Giovanini 2008 [47] & & & & $\checkmark$ \\
\hline & Signorini et al., 2013 [48] & & $\checkmark$ & $\checkmark$ & $\checkmark$ \\
\hline & Nauta et al., 2012 [49] & & & & $\checkmark$ \\
\hline & Uyttendaele et al., 2006 [50] & & & $\checkmark$ & $\checkmark$ \\
\hline $\begin{array}{l}\text { Salmonella spp. and } \\
\text { Campylobacter spp. }\end{array}$ & Pouillot et al., 2012 [51] & & & $\checkmark$ & $\checkmark$ \\
\hline \multirow{2}{*}{$\begin{array}{c}\text { Listeria } \\
\text { monocytogenes }\end{array}$} & Foerster et al. (2015) [52] & & & $\checkmark$ & $\checkmark$ \\
\hline & Aarnisalo et al. (2008) [53] & & & $\checkmark$ & $\checkmark$ \\
\hline $\begin{array}{l}\text { Clostridium } \\
\text { perfringens }\end{array}$ & Golden et al. (2009) [54] & & & $\checkmark$ & $\checkmark$ \\
\hline
\end{tabular}

The overview of collected studies (Figure 4) revealed that most of them focused on Salmonella spp. and thermotolerant Campylobacter species, especially during the consumption stage.

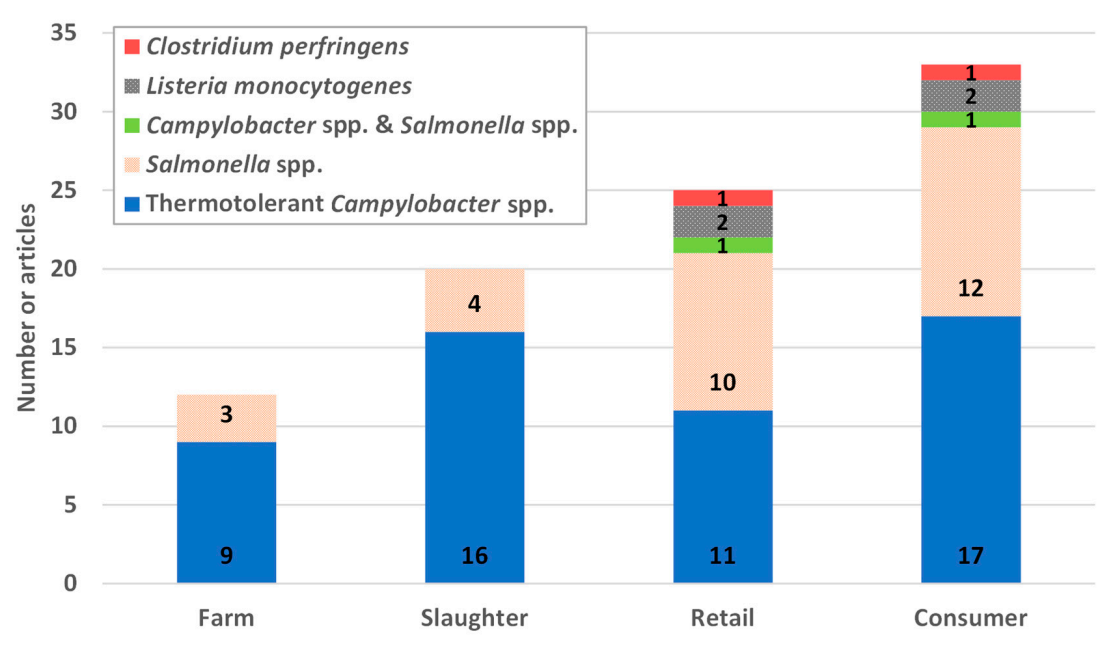

Figure 4. Frequency of farm-to-fork chain steps studied in the QMRA studies. 
The consumer part includes four distinct steps: storage, preparation, cooking, and consumption. Many studies have shown that food poisoning outbreaks occur mainly due to improper storage, cross contamination during preparation of meals, and inadequate heating during cooking [153-155]. Therefore, these three key aspects were analyzed below.

\subsection{Focus on the Consumer Step}

\subsubsection{Effect of Poultry Storage}

Poultry products are stored refrigerated or frozen, but in reality, cold chain failures may occur.

Concerning Salmonella spp. in poultry, most QMRA studies consider refrigerated storage as an essential step because proper storage conditions limit the growth of bacteria. Thus, most articles considered growth only during temperature abuse events above $5.2{ }^{\circ} \mathrm{C}$, which is considered as the minimal growth temperature for Salmonella spp. [13-15,17-21], or even no growth at all [23]. For example, a study by Collineau et al. (2020) showed the importance of storage temperature on the risk of salmonellosis [14]. According to this author, the effect of temperature abuse during storage, both at the consumers and in retail, would have a considerable impact on Salmonella spp. growth in poultry products. This effect could be more important in retail storage than in consumer storage because of the longer storage duration (average of 3.7 days versus 2.2 days) and the higher temperature achieved $\left(19.4{ }^{\circ} \mathrm{C}\right.$ vs. $\left.16^{\circ} \mathrm{C}\right)$. Straver et al. (2007) mentioned that there was little chance of finding a Salmonella-free chicken filet after domestic storage, but almost $50 \%$ chance to find $0-1 \log 10 \mathrm{CFU}$ per product [21]. Pouillot et al. (2012) performed a risk assessment on chicken meals prepared in households in Dakar by considering a long storage period at a relatively high ambient temperature before cooking (average time temperature profile: $4 \mathrm{~h}$ and $17 \mathrm{~min}$ at $29.3^{\circ} \mathrm{C}$ ) [51]. They showed that this storage before cooking would induce an average growth of $2.1 \log 10$ CFU of Salmonella spp. with a maximum of more than $4 \log 10 \mathrm{CFU}$ for a specific extreme reported time-temperature profile [51].

Additionally, for thermotolerant Campylobacter spp., storage conditions (refrigerated or frozen) can have an impact on the level of contamination on poultry carcasses by impairing the growth of bacteria and even reduce contamination levels $[37,46,48,71]$. The main assumption reported by studies was that thermotolerant Campylobacter spp. could not grow below $30^{\circ} \mathrm{C}$, was sensitive to freezing, and could also fairly survive under a cold and humid environment [48,50,156-158]. More precisely, Signorini et al. (2013) demonstrated that cold storage prevented thermotolerant Campylobacter spp. growth and even led to certain decreased levels, but there was still a proportion of the population that could survive [48,159]. Similarly, Brynestad et al. (2008) [46] reported in Germany a 2-log reduction during freezing with a decrease in viable cells to a very low level on the surface of chicken products. Additionally, Lindqvist and Lindblad (2008) estimated highly variable inactivation rates of thermotolerant Campylobacter spp. during the freezing of poultry (from 0.5 up to 3-4 $\log 10$ of inactivation) [37,159-163]. However, a data gap remains on temperature along the poultry farm-to-fork chain and more particularly during storage by consumers and also the state in which products are sold (i.e., fresh or frozen) [48]. The risk of human campylobacteriosis was assumed to be 4.10 times less in human when chicken carcasses were kept in frozen storage compared to non-frozen storage [48]. Finally, some studies have estimated the health impacts and found that fresh chicken legs with skin caused more than $90 \%$ of campylobacteriosis cases, although they are less consumed than breasts [46].

\subsubsection{Impact of Food Preparation}

The preparation stage of poultry products is also of concern as risks of cross-contamination are high before cooking $[14,16,19,20,51]$. During preparation, raw contaminated chicken may be put in contact with other foods or cooked meat ready to be consumed through food contact surfaces including cutting boards or knives, and consequently contaminating them [50]. For instance, Zhu et al. (2017) considered cross contamination in Chinese households via cutting boards as the factor responsible for 92.6\% (95\% CI, 78.6-99.0\%) of the contamination of ready-to-eat (RTE) foods by Salmonella spp. [19]. 
They concluded that on average, $0.51 \%$ of consumers might ingest one Salmonella spp. cell of each RTE food consumption through transfers from cutting boards contaminated with raw chicken [19]. This is likely to occur, considering that two third of households reported using the same cutting boards for raw chicken and RTE foods and, for half of them, boards were cleaned without any soap or reagents [19]. Consequently, the use of different cutting boards between raw chicken meat and RTE foods was identified as a key strategy to reduce the probability of illness [19,20,51], while an increased serving size was identified as a driver for an increase in Salmonella spp. [25]. The prevention of cross-contamination could correspond to a $28 \%$ decrease in the average likelihood of illness [14].

Concerning cross contamination of thermotolerant Campylobacter spp., food mishandling appears as the main factor of human campylobacteriosis. According to Brynestad et al. (2008), 74\% of campylobacteriosis cases in Germany were caused by cross contamination due to unhygienic practices such as not washing hands after handling raw chicken meat and no proper cleaning of kitchen utensils, resulting in 39\% and 35\% of campylobacteriosis cases, respectively [46]. Nevertheless, available data are very scarce concerning consumer behavior in the kitchen as identified by Uyttendaele et al. (2006) for the Belgian population [50]. According to their observations, between 25 to $76 \%$ of consumers in Belgium mishandle raw poultry at home [50]. In this study, it was noted that during cross contamination events, only bacteria present at the surface of meat were transferred [50]. Lindqvist and Lindblad (2008) estimated transfer rates during cross-contamination events from chicken to RTE foods or hands as within a range of $0.02 \%$ to $10 \%$ [37]. Concerning the impact of the contaminated surface, a study by Calistri and Giovanini (2008) showed that Campylobacter jejuni cells transferred from hands and utensils to RTE foods were linked to campylobacteriosis incidence in two Italian regions [47]. On the other hand, the QMRA model by Rosenquist et al. (2003) identified that cross contamination via unwashed cutting boards was supposed to be the most important route of transfer [39]. Signorini et al. (2013) estimated that thermotolerant Campylobacter spp. doses ingested by consuming contaminated salad due to mishandled poultry meat products in Argentina was of one or two bacteria per serving in most cases and the contamination prevalence was estimated around 33\% [48]. This paper also detailed the impact of hygienic practices adopted in private kitchens on the number of human campylobacteriosis cases. It articulated that adopting good hygienic practices in the kitchen could lower the exposure to thermotolerant Campylobacter spp. and hence lower the number of cases [48]. According to estimations made by these authors, if the cutting boards were washed instantly after handling raw poultry products, then the risk of human campylobacteriosis would undergo a ten-fold decrease approximately in comparison with the absence of cleaning [48]. In contrast, using the same unwashed cutting board to prepare the salad would increase the chances of salad contamination in comparison with the use of a washed cutting board [48]. The risk of human campylobacteriosis was also impacted by the preparation sequence If the same cutting board were used to prepare the whole meal, where RTE foods like salad should be prepared before raw poultry meat products, as if uncooked/raw chicken is prepared before salad, there is higher risk of causing campylobacteriosis than following the recommended sequence [48]. Authors also mentioned hand washing as an important step during food preparation at home with a risk increase by $>1.4$ if hands were unwashed [48]. In its 2018 report, Anses tested hand washing and utensil cleaning interventions in the kitchen as well as the combination of both [8]. In the case of full compliance, the risk reduction achieved is estimated to be $1 \%, 85 \%$, and $87 \%$ for hand washing, utensil cleaning, and combination of both, respectively.

\subsubsection{Inactivation of Bacteria during Cooking}

During poultry cooking, pathogens can be inactivated by heat treatment. However, some pathogens or their toxins may survive and cause illness after meal consumption. Depending on the cooking method, inactivation is more likely achieved on the product surface rather than on the core, as for pan cooking.

For Salmonella spp. in broilers, most authors considered that undercooking was an important factor of risk increase, emphasizing the importance of heat treatment [14-16,18,20,22,23,104]. As an 
indication of Salmonella spp. thermoresistance for chicken cooking, the D-value at $70{ }^{\circ} \mathrm{C}$ was around $6 \mathrm{~s}$ and $24 \mathrm{~min}$ at $55^{\circ} \mathrm{C}$, considering a $z$-value of $6.262^{\circ} \mathrm{C}$ [164]. Thermal inactivation depends on cooking temperature/time parameters, product shape and size as well as cooking method, but also the serotype and physiological state of cells [16]. Considering cooking of a whole poultry in oven, for example, non-uniform temperature distribution may result in "low-heat" zones protecting cells from inactivation $[14,165]$. According to the Salmonella spp. D value, a minimum cooking process is necessary, for a non-frozen chicken, with a core temperature of the product of $60^{\circ} \mathrm{C}$, for at least $8 \mathrm{~min}$ to reduce Salmonella spp. to a level at which the risk can be considered as negligible [164]. Achieving a high core temperature is likely to be easier for smaller products in combination with a suitable cooking method and may help to reduce illness risks. For example, a study by Bemrah et al. (2003) indicated that the risk of salmonellosis in French 'Cordon bleu' (reconstituted turkey meat turnover coated with breadcrumbs) was close to zero if the cooking temperature achieved at least $63^{\circ} \mathrm{C}$ at the core during oven cooking [22]. If the food was cooked using a fryer (i.e., shorter cooking time at a mean core temperature of $57^{\circ} \mathrm{C}$ ), the risk could not be eliminated, especially with a high initial number of bacteria [22]. Concerning the impact of cooking methods, stir-frying associated with traditional Korean and Japanese recipes like chicken sashimi does not enable the product to reach an internal cooking temperature as high as in frying and boiling and may lead to undercooked chicken meat products. This can sometimes also favor cross-contamination of vegetables from meat [23]. As an example, Oscar et al. (1998) considered in their modeling approach of the cooking step that $20 \%$ of chicken were undercooked, which could induce $1 \%$ to $10 \%$ survival of the Salmonella spp. population [15]. Cooking chicken to a mean temperature of $62^{\circ} \mathrm{C}\left(\min =55^{\circ} \mathrm{C}\right.$; $\left.\max =70^{\circ} \mathrm{C}\right)$ for a mean time of $30 \mathrm{~min}$ $(\min =15 \mathrm{~min} ; \max =45 \mathrm{~min}$, was estimated to decrease the number of contaminated chickens from 3000 to 16, with a mean Salmonella spp. level of 4.7 cells per contaminated chicken (min: 1 cell; max: 21 cell) [16]. Thus, the cooking temperature and microbial concentration had a predominant effect on the resulting probability of illness $[16,24]$ and adequate cooking would be even more important than the prevention of cross contamination with a reduction of salmonellosis risk by $64.3 \%$ and $27.6 \%$, respectively [14]. In addition, cooking unthawed frozen ground turkey burger observed in $2.2 \%$ of cases, resulted in $38-52 \%$ of the salmonellosis case numbers at home [24].

Concerning Campylobacter, Uyttendaele et al. (2006) described that under adequate heat treatment of poultry meat, thermotolerant Campylobacter spp. barely survives in poultry products due to the heat sensitive properties of this pathogen [36,50]. It concluded that improper heating of chicken products might result in higher exposure probability to the pathogen. This was reported by Brynestad et al. (2008), who stated that undercooking of a poultry product contaminated by thermotolerant Campylobacter spp. caused 3\% of German illness cases [46]. During undercooking, up to $20 \%$ of thermotolerant Campylobacter spp. cells are able to survive in protected areas of the poultry product $[40,41,50]$. This proportion of cells was determined by the report of the FAO/WHO (2002), describing that once the outside heating temperature of a meat product had reached $74^{\circ} \mathrm{C}$, then the inside temperature was around $60-65^{\circ} \mathrm{C}$ within 0.5 to $1.5 \mathrm{~min}[40,41,165]$. This paper also mentioned that since the D-value of thermotolerant Campylobacter spp, for poultry was less than $1 \mathrm{~min}$ at $60^{\circ} \mathrm{C}$, compared to $3.8 \mathrm{~min}$ for Salmonella spp. [164], it should be efficiently inactivated by temperatures set to inactivate Salmonella spp. [166].

\subsubsection{Influence of the Consumer Behavior during Serving}

Consumer behavior during serving refers to at-home practices after product cooking that may have an impact on risk of illness. Regarding Salmonella spp., potential storage conditions after cooking, duration before consumption, and dressing with utensils previously used for raw meat were investigated $[16,17,20-22,51,104,114]$. Additionally, a Salmonella-free meal could be contaminated from the use of the same cutting boards, utensils, or unwashed hands as for the raw meat preparation for cooked meal dressing or salad preparation (see Section 3.5.4 for the latter) $[20,104,114]$. For instance, a Canadian survey estimated that $0.6 \%$ of consumers did not wash their hands and $1 \%$, their cutting 
boards after raw meat handling [20]. By aggregating data from several studies, they estimated the transfer from contaminated hands varying between $0.14 \%$ and $52.95 \%$ with a most likely value of $8.93 \%$ and the transfer from boards varying between $10.49 \%$ and $42.38 \%$, with a most likely value of $19.40 \%$ [20]. Oscar estimated that this pathogen transfer could nearly double the contamination level of cooked chicken at consumption from 21 to 39 cells [16], and later identified a linear relationship between frequency of improper serving and salmonellosis incidence [17].

Concerning thermotolerant Campylobacter spp. in poultry meat preparations, Uyttendaele et al. (2006) described that in order to reduce exposure, limiting the consumption of raw/uncooked meat is also important, along with reducing the contamination level of thermotolerant Campylobacter spp. Consequently, communication campaigns are required to warn consumers of the risks in consuming raw poultry [50]. Concerning cross-contamination of cooked chicken, Campylobacter species are known to be able to easily transfer (i.e., in $80 \%$ of contact events of $10 \mathrm{~s}$ from raw meat to cutting board and in $30 \%$ of contact events from the board to the cooked meat) [8]. This kind of direct contamination from utensils/hands has also been considered in several other studies $[39,45-48,50]$. Cross-contamination when using unwashed utensils/hands was also simulated by developing a "drip-fluid" model. This model considered the leakage of a contaminated fluid, consisting of a mixture of chicken blood and residual water gained during processing and during meal preparation [30,40,41]. Nevertheless, data gaps persist for some factors like the impact of contact area between raw meat and board as well as the time elapsed between consecutive contacts of raw followed by cooked meat with the board [39].

\section{Discussion}

\subsection{Summary of Mitigation Interventions Applicable at the Consumer Step}

Considering the 43 QMRA studies collected, most studies addressed the impact of the consumer behavior. The main risk factors and mitigation measures in the consumption step were identified in Table 3 for the main pathogens Salmonella spp. and thermotolerant Campylobacter spp. Consumers have an impact on the final level of contamination of the product due to conditions of storage, preparation, cooking, and post-cooking handling. In particular, cross-contamination occurring during both food preparation and final dressing as well as undercooking of the meat were put forward as high risk factors to address. To avoid pathogen survival and growth, measures suggested to be taken by consumers include thawing frozen meat before cooking, use of a meat thermometer to ensure the target internal temperature, prepare side ingredients before the raw meat, or never reuse an unwashed cutting board for both raw and cooked meat. Cooking can inactivate Salmonella spp. at $70{ }^{\circ} \mathrm{C}$ for at least $1 \mathrm{~min}$ and thermotolerant Campylobacter spp. at temperatures above $60^{\circ} \mathrm{C}$ for longer than $1 \mathrm{~min}$. 
Table 3. Main risk factors and mitigation measures suggested in the consumer step.

\begin{tabular}{|c|c|c|c|}
\hline Step & Risk Factors & Risk Mitigation Measure & References \\
\hline \multirow{6}{*}{ Storage } & \multirow{2}{*}{ Temperature abuses } & Respect of temperatures $<4^{\circ} \mathrm{C}$ & {$[14,16,17,19,21,48,50,51]$} \\
\hline & & Monitoring & {$[48]$} \\
\hline & $\begin{array}{l}\text { Survival of thermotolerant } \\
\text { Campylobacter spp. in fridge }\end{array}$ & Freeze $\left(-20^{\circ} \mathrm{C}, \geq 24 \mathrm{~h}\right)$ & {$[32,37,43,44,46,48]$} \\
\hline & \multirow{3}{*}{ Cross-contamination } & $\begin{array}{l}\text { Change/wash utensils and wash } \\
\text { hands between preparations }\end{array}$ & {$[8,19,20,46,48,50,51,166]$} \\
\hline & & Consumer education & {$[14,32]$} \\
\hline & & $\begin{array}{c}\text { Prepare raw meat after other } \\
\text { ingredients }\end{array}$ & [48] \\
\hline \multirow{3}{*}{ Cooking } & \multirow{3}{*}{ Undercooking } & Thaw frozen meat before cooking & [24] \\
\hline & & $\begin{array}{l}\text { Adapt cooking methods to } \\
\text { product's shape and size to facilitate } \\
\text { heat transfer }\end{array}$ & {$[16,22,25]$} \\
\hline & & Core temperature $>70^{\circ} \mathrm{C}$ & {$[14,16,18,20,22-25,40,41,46,51]$} \\
\hline \multirow{5}{*}{ Consumer behavior } & Storage after cooking & Store at heat (stove for example) & [22] \\
\hline & \multirow{2}{*}{ Cross-contamination } & $\begin{array}{l}\text { Change or wash utensils and hands } \\
\text { between preparations }\end{array}$ & $\begin{array}{c}{[8,16,17,20,30,32,39-41,45-48,} \\
50,51,166]\end{array}$ \\
\hline & & Consumer's education & [14] \\
\hline & Consumption of raw meat & Communication campaigns to limit & {$[23,32,50]$} \\
\hline & Data gaps & $\begin{array}{c}\text { National surveys on consuming } \\
\text { behaviors }\end{array}$ & [39] \\
\hline
\end{tabular}

\subsection{Geographical Specificities within the Poultry Meat Chain}

It has to be noted that regardless the country, Salmonella spp. and Campylobacter spp. are very often ranked amongst pathogens most associated with the burden of foodborne diseases [1]. Salmonella spp. and Campylobacter spp. were also found as the top microbial hazards considered in the risk assessment of the poultry chain regardless of country $[23,25,28,48,51]$. Regarding the guidelines and regulations, these were generally found to be similar, especially in developed countries. However, some specificities associated with regions, customs, or individual behaviors were also observed [8,28,51,54,167].

Concerning processing, there were almost no differences considering the steps occurring at the slaughterhouse [9], except for some specificities related to carcass decontamination, as underlined by the EFSA and Anses reports [8,28]. Thus, chemical decontamination of poultry carcasses, which encompasses washes using organic acids, chlorinated, or electrolyzed water as well as peracetic acid, acidified sodium chlorite, or trisodium phosphate is currently not authorized for any poultry products intended to be sold in the EU market, contrary to other non-EU regions [28]. Moreover, several EU countries prohibit the use of irradiation, either gamma radiation or $\mathrm{x}$-rays, for carcass decontamination [28]. There are also some mitigation strategies that are routinely applied only in some countries (Norway, Iceland, and Denmark) like scheduled slaughtering, which consists in the testing of carcasses before slaughter to identify positive carcasses requiring additional microbial reduction treatments compared to negative ones [28].

Considering the other parts of the meat chain, more differences may occur at the farm, retail, and at the consumer points. If no data were available in the collected papers concerning the farm step, two papers provided information concerning the two latter steps in developing and East Asian countries [23,51]. Thus, considering retail in Senegal, the dedicated "market-to-fork" published by Pouillot et al. pointed out that chickens were sold alive and slaughtered at the time of sale, without prior refrigerated storage [51]. This greatly differs from what is known about cold chain compliance regulations concerning the retail sale of poultry meat. On the other hand, Jeong et al. explicitly considered South Korean cooking behavior observed for traditional dishes to build its QMRA study, which implies an increased risk of meat undercooking [23]. Moreover, authors have highlighted 
local cooking specificities that can have a significant impact on food safety, with the examples of chicken stir-frying and sashimi (meat consumed raw).

Among all steps of the poultry farm-to-fork chain, the consumer's behavior represents the most variable factor across geographical regions because it is related to cultural preparation and cooking habits $[8,167]$. This is pushed forward by the FAO and WHO, who consider that little is known about the consumer's behavior and that its monitoring remains difficult, despite being reliable [168]. Thus, a great discrepancy of behaviors can be observed at the global scale as well as at individual scale. At a global scale, several specificities are observed according to regions. When considering African regions, Pouillot et al. emphasized the fact that consumers tend to expose chicken carcasses to hazardous environmental conditions (i.e., storage at temperature above $17.5^{\circ} \mathrm{C}$ for several hours) [51]. Other examples can be given when considering consumers from developed countries, with specificities associated with traditional recipes leading to potential undercooking [23] or general consumer compliance to hygienic practices associated with ethnicity, gender, or education $[8,167]$.

\subsection{Consumer Education with Regard to the Whole Farm-to-Fork Chain}

Authorities and managers also have to make sure that mitigation measures are applied along all parts of the farm-to-fork chain and more particularly, interventions realized at the consumer step as they are expected to have the biggest impact on the risk reduction of illness. Indeed, upstream efforts at any stage that prevent contamination and reduce the contamination level will later reduce illness risk to a greater extent.

The impact of mitigation interventions applied at the pre-slaughter, processing, and post-processing stages was assessed by authors by testing alternative scenarios and conducting sensitivity analysis. Among the QMRAs collected, some studies covered the whole farm-to-fork chain and assessed interventions and risk factors for every part of it $[8,14,18,28,30,32-34]$. The majority of studies agree on the high impact of the role of the consumer on the microbial safety of the serving $[8,14,30]$. For instance, risk reductions could be decreasingly achieved by adequate cooking, avoiding cross-contamination by utensils and hand washing, and compliance with adequate storage temperature [14,30]. In contrast, two studies considered that the intervention measures most efficient in risk reduction were rather found in the processing and pre-processing steps by limiting fecal leakage during processing, scheduled slaughtering, and decontaminating flocks [32,34].

Apart from the consumer behavior and considering both pathogens of interest, efforts should focus on reducing the introduction of contaminated animals into the slaughterhouse by intervening at the farm $[8,14,32,34]$, avoiding cross-contamination at the slaughterhouse [14,30,32], and ensuring proper cold storage at retail points $[14,34]$. More precisely, farm interventions such as cleaning between flocks are expected to reduce illness risk by $16 \%$ [8], but measures like poultry vaccination of phage usage, which are currently unavailable, may reduce it up to $93 \%$ [8,32,34]. Increased caution to reduce contamination spreading at scalding, evisceration, plucking, and even avoiding chilled baths can achieve high risk reductions [8,30,32].

When assessed, combined interventions always turn out to be the most efficient, especially when covering the whole farm-to-fork chain $[8,30]$. As an example, by combining the most efficient interventions at each stage of the chain, it is possible to reduce the campylobacteriosis risk by $99 \%$ [8]. Risk management through guidelines and regulations aim to target risk reduction throughout the meat chain. However, risk management at the level of the consumer remains difficult. It may only be achieved by consumer education on adequate handling and cooking practices, which, if thoroughly applied by the population, could have a greater impact on public health compared to other risk reduction methods [169-171]. In parallel to these communication campaigns, data gaps need to be addressed when speaking of consumption habits. Large uncertainty remains concerning the latter, impairing both robustness and efficiency of QMRAs and the design of education campaigns. To do so, national-level surveys are regularly conducted by several countries, revealing relevant information on, for example, the duration and mean refrigeration temperature of the storage of meat after purchase or 
the willingness to wash hands and utensils between preparations $[8,16,19,20,24,39,40,46,48,50]$. When not available or not suited to their studies, authors had to conduct such surveys by themselves $[19,51]$. In a guidance for microbiological risk assessment of food, the FAO and WHO have also suggested gathering data as quantitative and descriptive as possible regarding temperatures, durations, level of contamination, and transfer rates to be able to use predictive models to assess the level of contamination at these specific steps. Observation of food handling practices through purpose-built food preparation kitchens and video captures are also encouraged [168]. Quantitative data are indeed crucial for QMRAs to assess the impact of consumer habits on the risk of illness and evaluate and rank the efficiency of intervention measures [24].

Additionally, these surveys help to adapt communication campaigns to different cooking habits affected by factors like culture. Among the collected papers, some dealt with the cooking habits of African and Asian cultures, with their specificities and limitations [23,51]. Pouillot et al., while assessing salmonellosis and campylobacteriosis risks from consumption of home-prepared meals in Dakar (Senegal), highlighted the absence of refrigerated storage and the difficulties to achieve proper pathogen removal during slaughter (done at market) [51]. Jeong et al. emphasized the impact of traditional cooking methods (i.e., cooking in a pan or fryer) that fail to achieve effective heat treatment at the product's core [23]. Moreover, not considering these traditional methods can lead to voluntary ignorance or rejection of education campaigns, as observed in other circumstances such as medical burials during the last Ebola outbreak [172]. Education campaigns should also be presented as advice rather than regulations to be followed in order to reach a greater audience. Several methods can be used such as the nudge method. Nudges can be used along with education to incite the consumer to follow guidelines by making it easy and beneficial for them [173]. Finally, frequent surveys help to estimate the impact of education campaigns on the improvement of handling behaviors in kitchens [169-171].

\section{Conclusions}

Poultry contamination by pathogenic bacteria is known to occur at almost every step of the farm-to-fork chain. The use of a risk-based assessment method to improve general food safety is a key strategy currently promoted by national and international health authorities in all food sectors including poultry. However, the amount and heterogeneity of QMRA studies available make it difficult to easily grasp all the risk factors, data gaps, and areas for improvement. To bring some light on the most relevant issues to address, this review summarized available data from published QMRA studies dealing with poultry meat contamination using a systematic review procedure.

This study collated the available scientific resources regarding quantitative microbial risk assessment studies in poultry meat. In doing so, it highlights the effective implementation of the PRISMA methodology in using evidence-based data sources to inform an evaluation of intervention methods, resulting in an emphasis in this study on the central role of consumer behavior in influencing food safety risk. Consumers have a key role to play for the end-product safety. This is especially true regarding the new consumption trends appearing today such as the rise of homemade meals or storage habits, and the fact that consumer food handling is the final step of the meat chain. Many uncertainties remain concerning the consumption habits of the population, varying with social position, location, and cultural aspects. However, by characterizing the specific features associated with those trends and aspects and thus improving knowledge of the population, QMRAs can be fed with high quality data, leading to more accurate risk assessment as well as intervention strategies and education campaigns. Thus, ascertaining more data regarding consumer habits should lead to improved understanding of pathogen interactions in the domestic environment with the ultimate aim to reduce their persistence and improve public health. This study provided an expert overview of the importance of the role of the consumer and the issues associated with the variability of storage and cooking behaviors as well as the difficulty to assess these behaviors. 
Author Contributions: Conceptualization, T.K., A.H., M.F., E.C., G.B., S.G., and V.T.; Methodology, T.K., A.H., M.F., E.C., G.B., S.G., and V.T.; Investigation, T.K., G.B., S.G., and V.T.; data curation, T.K., V.T.; writing-original draft preparation, T.K.; writing-review and editing, T.K., A.H., M.F., E.C., G.B., S.G., and V.T.; Visualization, T.K., S.G., and V.T.; Project administration, M.F., G.B., S.G., and V.T.; Funding acquisition, G.B. All authors have read and agreed to the published version of the manuscript.

Funding: This research was funded by the regional program "Food for Tomorrow/Cap Aliment; Research, Education and Innovation in Pays de la Loire", which is supported by the French Region Pays de la Loire and the European Found for the Regional Development (FEDER).

Conflicts of Interest: The authors declare no conflict of interest.

\section{References}

1. Kirk, M.D.; Pires, S.M.; Black, R.E.; Caipo, M.; Crump, J.A.; Devleesschauwer, B.; Döpfer, D.; Fazil, A.; Fischer-Walker, C.L.; Hald, T.; et al. World Health Organization Estimates of the Global and Regional Disease Burden of 22 Foodborne Bacterial, Protozoal, and Viral Diseases, 2010: A Data Synthesis. PLoS Med. 2015, 12, e1001921. [CrossRef]

2. European Food Safety Authority (EFSA); European Centre for Disease Prevention and Control (ECDC). The European Union One Health 2018 Zoonoses Report. EFSA J. 2019, 17, 05926. [CrossRef]

3. Kelly, L.A.; Hartnett, E.; Gettinby, G.; Fazil, A.; Snary, E.; Wooldridge, M. Microbiological safety of poultry meat: Risk assessment as a way forward. Worlds Poult. Sci. J. 2003, 59, 495-508. [CrossRef]

4. Humphrey, T.; O’Brien, S.; Madsen, M. Campylobacters as zoonotic pathogens: A food production perspective. Int. J. Food Microbiol. 2007, 117, 237-257. [CrossRef] [PubMed]

5. Global Epidemiology of Campylobacter Infection|Clinical Microbiology Reviews. Available online: https: //cmr.asm.org/content/28/3/687 (accessed on 5 May 2020).

6. Vellinga, A. The Dioxin Crisis as Experiment to Determine Poultry-Related Campylobacter Enteritis. Emerg. Infect. Dis. 2002, 8, 19-22. [CrossRef] [PubMed]

7. Food and Agriculture Organization-Organization for Economic Co-operation and Development. Chapter 6: Meat. In OECD-FAO Agricultural Outlook 2018-2027; OECD Publishing: Paris, France; Food and Agriculture Organization of the United Nations: Rome, Italy, 2018; pp. 149-162.

8. Anses. State of Knowledge Relating to the Contamination of Broilers with Campylobacter and Assessment of the Impact of Interventions at Different Stages of the Food Chain in France; Collective Expert Appraisal Report; Anses: Fougères, France, 2018; p. 104.

9. Chapman, B.; Otten, A.; Fazil, A.; Ernst, N.; Smith, B.A. A review of quantitative microbial risk assessment and consumer process models for Campylobacter in broiler chickens. Microb. Risk Anal. 2016, 2, 3-15. [CrossRef]

10. Membré, J.-M.; Boué, G. Quantitative microbiological risk assessment in food industry: Theory and practical application. Food Res. Int. 2018, 106, 1132-1139. [CrossRef]

11. Moher, D.; Liberati, A.; Tetzlaff, J.; Altman, D.G.; PRISMA Group. Preferred reporting items for systematic reviews and meta-analyses: The PRISMA statement. PLoS Med. 2009, 6, e1000097. [CrossRef]

12. Liberati, A.; Altman, D.G.; Tetzlaff, J.; Mulrow, C.; Gøtzsche, P.C.; Ioannidis, J.P.A.; Clarke, M.; Devereaux, P.J.; Kleijnen, J.; Moher, D. The PRISMA Statement for Reporting Systematic Reviews and Meta-Analyses of Studies That Evaluate Health Care Interventions: Explanation and Elaboration. PLoS Med. 2009, 6, e1000100. [CrossRef]

13. Bucher, O.; Fazil, A.; Rajić, A.; Farrar, A.; Wills, R.; McEWEN, S.A. Evaluating interventions against Salmonella in broiler chickens: Applying synthesis research in support of quantitative exposure assessment. Epidemiol. Infect. 2012, 140, 925-945. [CrossRef]

14. Collineau, L.; Chapman, B.; Bao, X.; Sivapathasundaram, B.; Carson, C.A.; Fazil, A.; Reid-Smith, R.J.; Smith, B.A. A farm-to-fork quantitative risk assessment model for Salmonella Heidelberg resistant to third-generation cephalosporins in broiler chickens in Canada. Int. J. Food Microbiol. 2020, 330, 108559. [CrossRef]

15. Oscar, T.P. The Development of a Risk Assessment Model for Use in the Poultry Industry. J. Food Saf. 1998, 18, 371-381. [CrossRef]

16. Oscar, T.P. A quantitative risk assessment model for Salmonella and whole chickens. Int. J. Food Microbiol. 2004, 93, 231-247. [CrossRef] [PubMed] 
17. Oscar, T.P. Risk of Salmonellosis from Chicken Parts Prepared from Whole Chickens Sold in Flow Pack Wrappers and Subjected to Temperature Abuse. J. Food Prot. 2017, 80, 1496-1505. [CrossRef] [PubMed]

18. Maijala, R.; Ranta, J.; Seuna, E.; Pelkonen, S.; Johansson, T. A quantitative risk assessment of the public health impact of the Finnish Salmonella control program for broilers. Int. J. Food Microbiol. 2005, 102, 21-35. [CrossRef] [PubMed]

19. Zhu, J.; Bai, Y.; Wang, Y.; Song, X.; Cui, S.; Xu, H.; Jiao, X.; Li, F. A risk assessment of salmonellosis linked to chicken meals prepared in households of China. Food Control 2017, 79, 279-287. [CrossRef]

20. Smadi, H.; Sargeant, J.M. Quantitative Risk Assessment of Human Salmonellosis in Canadian Broiler Chicken Breast from Retail to Consumption. Risk Anal. 2013, 33, 232-248. [CrossRef]

21. Straver, J.M.; Janssen, A.F.W.; Linnemann, A.R.; van Boekel, M.A.J.S.; Beumer, R.R.; Zwietering, M.H. Number of Salmonella on Chicken Breast Filet at Retail Level and Its Implications for Public Health Risk. J. Food Prot. 2007, 70, 2045-2055. [CrossRef]

22. Bemrah, N.; Bergis, H.; Colmin, C.; Beaufort, A.; Millemann, Y.; Dufour, B.; Benet, J.J.; Cerf, O.; Sanaa, M. Quantitative risk assessment of human salmonellosis from the consumption of a turkey product in collective catering establishments. Int. J. Food Microbiol. 2003, 80, 17-30. [CrossRef]

23. Jeong, J.; Chon, J.-W.; Kim, H.; Song, K.-Y.; Seo, K.-H. Risk Assessment for Salmonellosis in Chicken in South Korea: The Effect of Salmonella Concentration in Chicken at Retail. Korean J. Food Sci. Anim. Resour. 2018, 38, 1043-1054. [CrossRef]

24. Sampedro, F.; Wells, S.J.; Bender, J.B.; Hedberg, C.W. Developing a risk management framework to improve public health outcomes by enumerating Salmonella in ground turkey. Epidemiol. Infect. 2019, 147, e69. [CrossRef] [PubMed]

25. Oscar, T.P. Process risk model for Salmonella and ground chicken. J. Appl. Microbiol. 2019, 127, 1236-1245. [CrossRef]

26. Hartnett, E.; Kelly, L.; Newell, D.; Wooldridge, M.; Gettinby, G. A quantitative risk assessment for the occurrence of Campylobacter in chickens at the point of slaughter. Epidemiol. Infect. 2001, 127, 195-206. [CrossRef] [PubMed]

27. Crotta, M.; Georgiev, M.; Guitian, J. Quantitative risk assessment of Campylobacter in broiler chickens-Assessing interventions to reduce the level of contamination at the end of the rearing period. Food Control 2017, 75, 29-39. [CrossRef]

28. European Food Safety Authority. Scientific Opinion on Campylobacter in broiler meat production: Control options and performance objectives and/or targets at different stages of the food chain. EFSA J. 2011, 9, 2105. [CrossRef]

29. Romero-Barrios, P.; Hempen, M.; Messens, W.; Stella, P.; Hugas, M. Quantitative microbiological risk assessment (QMRA) of food-borne zoonoses at the European level. Food Control 2013, 29, 343-349. [CrossRef]

30. Dogan, O.B.; Clarke, J.; Mattos, F.; Wang, B. A quantitative microbial risk assessment model of Campylobacter in broiler chickens: Evaluating processing interventions. Food Control 2019, 100, 97-110. [CrossRef]

31. Nauta, M.J.; Jacobs-Reitsma, W.F.; Evers, E.G.; van Pelt, W.; Havelaar, A.H. Risk Assessment of Campylobacter in the Netherlands via Broiler Meat and Other Routes; RIVM: Bilthoven, The Netherlands, 2005; p. 128.

32. Havelaar, A.H.; Mangen, M.-J.J.; Koeijer, A.A.D.; Bogaardt, M.-J.; Evers, E.G.; Jacobs-Reitsma, W.F.; Pelt, W.V.; Wagenaar, J.A.; Wit, G.A.D.; Zee, H.V.D.; et al. Effectiveness and efficiency of controlling Campylobacter on broiler chicken meat. Risk Anal. 2007, 27, 831-844. [CrossRef]

33. Katsma, W.E.A.; De Koeijer, A.A.; Jacobs-Reitsma, W.F.; Mangen, M.-J.J.; Wagenaar, J.A. Assessing Interventions to Reduce the Risk of Campylobacter Prevalence in Broilers. Risk Anal. 2007, 27, 863-876. [CrossRef]

34. Nauta, M.J.; Jacobs-Reitsma, W.F.; Havelaar, A.H. A Risk Assessment Model for Campylobacter in Broiler Meat. Risk Anal. 2007, 27, 845-861. [CrossRef]

35. Huang, J.; Zang, X.; Zhai, W.; Guan, C.; Lei, T.; Jiao, X. Campylobacter spp. in chicken-slaughtering operations: A risk assessment of human campylobacteriosis in East China. Food Control 2018, 86, 249-256. [CrossRef]

36. Wang, J.; Guo, Y.C.; Li, N. Prevalence and Risk Assessment of Campylobacter jejuni in Chicken in China. Biomed. Environ. Sci. 2013, 26, 243-248. [CrossRef] [PubMed]

37. Lindqvist, R.; Lindblad, M. Quantitative risk assessment of thermophilic Campylobacter spp. and cross-contamination during handling of raw broiler chickens evaluating strategies at the producer level to reduce human campylobacteriosis in Sweden. Int. J. Food Microbiol. 2008, 121, 41-52. [CrossRef] [PubMed] 
38. Osiriphun, S.; Iamtaweejaloen, P.; Kooprasertying, P.; Koetsinchai, W.; Tuitemwong, K.; Erickson, L.E.; Tuitemwong, P. Exposure assessment and process sensitivity analysis of the contamination of Campylobacter in poultry products. Poult. Sci. 2011, 90, 1562-1573. [CrossRef] [PubMed]

39. Rosenquist, H.; Nielsen, N.L.; Sommer, H.M.; Nørrung, B.; Christensen, B.B. Quantitative risk assessment of human campylobacteriosis associated with thermophilic Campylobacter species in chickens. Int. J. Food Microbiol. 2003, 83, 87-103. [CrossRef]

40. Food and Agriculture Organization of the United Nations. Risk Assessment of Campylobacter spp. in Broiler Chickens: Technical Report; World Health Organization/Food and Agriculture Organization of the United Nations, FAO, Eds.; Microbiological Risk Assessment Series; World Health Organization: Geneva, Switzerland, 2009; ISBN 978-92-4-154736-9.

41. Food and Agriculture Organization of the United Nations. Risk Assessment of Campylobacter spp. in Broiler Chickens: Interpretary Summary; World Health Organization/Food and Agriculture Organization of the United Nations, Ed.; Microbiological Risk Assessment Series; World Health Organization: Geneva, Switzerland, 2009; ISBN 978-92-4-154735-2.

42. Nauta, M.; Lindqvist, R.; Georgsson, F.; Hogåsen, H.; Hielm, S.; Tuominen, P.; Ranta, J.; Rosenquist, H.; Andersen, J.K. Establishment of Risk Based Microbiological Criteria in the Nordic Countries: A Case Study on Campylobacter in Broiler Meat; National Food Institute, Technical University of Denmark, DTU: Copenhagen, Denmark, 2013; ISBN 978-87-92763-83-9.

43. Boysen, L. Campylobacter in Denmark: Control, Human Risk and Source Attribution. Ph.D. Thesis, National Food Institute, Technical University of Denmark, Søborg, Denmark, 2012. ISBN 978-87-92763-22-8.

44. Boysen, L.; Nauta, M.; Duarte, A.S.R.; Rosenquist, H. Human risk from thermotolerant Campylobacter on broiler meat in Denmark. Int. J. Food Microbiol. 2013, 162, 129-134. [CrossRef]

45. Christensen, B.B.; Nauta, M.; Korsgaard, H.; Sørensen, A.I.V.; Rosenquist, H.; Boysen, L.; Perge, A.; Nørrung, B. Case-by-case risk assessment of broiler meat batches: An effective control strategy for Campylobacter. Food Control 2013, 31, 485-490. [CrossRef]

46. Brynestad, S.; Braute, L.; Luber, P.; Bartelt, E. Quantitative microbiological risk assessment of campylobacteriosis cases in the German population due to consumption of chicken prepared in homes. Int. J. Risk Assess. Manag. 2008, 8, 194. [CrossRef]

47. Calistri, P.; Giovannini, A. Quantitative risk assessment of human campylobacteriosis related to the consumption of chicken meat in two Italian regions. Int. J. Food Microbiol. 2008, 128, 274-287. [CrossRef]

48. Signorini, M.L.; Zbrun, M.V.; Romero-Scharpen, A.; Olivero, C.; Bongiovanni, F.; Soto, L.P.; Frizzo, L.S.; Rosmini, M.R. Quantitative risk assessment of human campylobacteriosis by consumption of salad cross-contaminated with thermophilic Campylobacter spp. from broiler meat in Argentina. Prev. Vet. Med. 2013, 109, 37-46. [CrossRef]

49. Nauta, M.J.; Sanaa, M.; Havelaar, A.H. Risk based microbiological criteria for Campylobacter in broiler meat in the European Union. Int. J. Food Microbiol. 2012, 158, 209-217. [CrossRef] [PubMed]

50. Uyttendaele, M.; Baert, K.; Ghafir, Y.; Daube, G.; De Zutter, L.; Herman, L.; Dierick, K.; Pierard, D.; Dubois, J.J.; Horion, B.; et al. Quantitative risk assessment of Campylobacter spp. in poultry based meat preparations as one of the factors to support the development of risk-based microbiological criteria in Belgium. Int. J. Food Microbiol. 2006, 111, 149-163. [CrossRef] [PubMed]

51. Pouillot, R.; Garin, B.; Ravaonindrina, N.; Diop, K.; Ratsitorahina, M.; Ramanantsoa, D.; Rocourt, J. A Risk Assessment of Campylobacteriosis and Salmonellosis Linked to Chicken Meals Prepared in Households in Dakar, Senegal. Risk Anal. 2012, 32, 1798-1819. [CrossRef] [PubMed]

52. Foerster, C.; Figueroa, G.; Evers, E. Risk assessment of Listeria monocytogenes in poultry and beef. Br. Food J. 2015, 117, 779-792. [CrossRef]

53. Aarnisalo, K.; Vihavainen, E.; Rantala, L.; Maijala, R.; Suihko, M.; Hielm, S.; Tuominen, P.; Ranta, J.; Raaska, L. Use of results of microbiological analyses for risk-based control of Listeria monocytogenes in marinated broiler legs. Int. J. Food Microbiol. 2008, 121, 275-284. [CrossRef]

54. Golden, N.J.; Crouch, E.A.; Latimer, H.; Kadry, A.-R.; Kause, J. Risk Assessment for Clostridium perfringens in Ready-to-Eat and Partially Cooked Meat and Poultry Productst. J. Food Prot. 2009, 72, 1376-1384. [CrossRef]

55. Chien, S.-Y.; Sheen, S.; Sommers, C.H.; Sheen, L.-Y. Modeling the Inactivation of Intestinal Pathogenic Escherichia coli O157:H7 and Uropathogenic E. coli in Ground Chicken by High Pressure Processing and Thymol. Front. Microbiol. 2016, 7, 920. [CrossRef] 
56. Dominguez, S.A.; Schaffner, D.W. Modeling the Growth of Salmonella in Raw Poultry Stored under Aerobic Conditions. J. Food Prot. 2008, 71, 2429-2435. [CrossRef]

57. Genigeorgis, C.A.; Meng, J.; Baker, D.A. Behavior of Nonproteolytic Clostridium botulinum Type B and E Spores in Cooked Turkey and Modeling Lag Phase and Probability of Toxigenesis. J. Food Sci. 1991, 56, 373-379. [CrossRef]

58. Ghollasi-Mood, F.; Mohsenzadeh, M.; Hoseindokht, M.-R.; Varidi, M. Quality changes of air-packaged chicken meat stored under different temperature conditions and mathematical modelling for predicting the microbial growth and shelf life: Ghollasi-Mood, et al. J. Food Saf. 2017, 37, e12331. [CrossRef]

59. Guentert, A.M.; Mohtar, R.H.; Linton, R.H.; Tamplin, M.; Luchansky, J.B. Modeling the Behavior of Listeria monocytogenes in $\mathrm{pH}$-modified Chicken Salad During Cold Storage and Temperature Abuse Conditions. J. Food Process Eng. 2006, 29, 89-117. [CrossRef]

60. Hu, J.; Lin, L.; Chen, M.; Yan, W. Modeling for Predicting the Time to Detection of Staphylococcal Enterotoxin A in Cooked Chicken Product. Front. Microbiol. 2018, 9, 1536. [CrossRef] [PubMed]

61. Huang, C.-Y.; Sheen, S.; Sommers, C.; Sheen, L.-Y. Modeling the Survival of Escherichia coli O157:H7 under Hydrostatic Pressure, Process Temperature, Time and Allyl Isothiocyanate Stresses in Ground Chicken Meat. Front. Microbiol. 2018, 9, 1871. [CrossRef] [PubMed]

62. Juneja, V.K.; Melendres, M.V.; Huang, L.; Gumudavelli, V.; Subbiah, J.; Thippareddi, H. Modeling the effect of temperature on growth of Salmonella in chicken. Food Microbiol. 2007, 24, 328-335. [CrossRef]

63. Keklik, N.M.; Demirci, A.; Puri, V.M.; Heinemann, P.H. Modeling the Inactivation of Salmonella Typhimurium, Listeria monocytogenes, and Salmonella Enteritidis on Poultry Products Exposed to Pulsed UV Light. J. Food Prot. 2012, 75, 281-288. [CrossRef]

64. Li, M.; Huang, L.; Zhu, Y.; Wei, Q. Growth of Clostridium Perfringens in roasted chicken and braised beef during cooling-One-step dynamic analysis and modeling. Food Control 2019, 106, 106739. [CrossRef]

65. McCarthy, Z.; Smith, B.; Fazil, A.; Wu, J.; Ryan, S.D.; Munther, D. Individual based modeling and analysis of pathogen levels in poultry chilling process. Math. Biosci. 2017, 294, 172-180. [CrossRef]

66. Meng, J.; Genigeorgis, C.A. Modeling lag phase of nonproteolytic Clostridium botulinum toxigenesis in cooked turkey and chicken breast as affected by temperature, sodium lactate, sodium chloride and spore inoculum. Int. J. Food Microbiol. 1993, 19, 109-122. [CrossRef]

67. Osaili, T.M.; Griffis, C.L.; Martin, E.M.; Gbur, E.E.; Marcy, J.A. Modeling Cooking Time to Inactivate Salmonella in Chicken Leg Quarters Cooked in an Air Steam Impingement Oven. J. Food Sci. 2006, 71, M146-M149. [CrossRef]

68. Oscar, T.P. Simulation Model for Enumeration of Salmonella on Chicken as a Function of PCR Detection Time Score and Sample Size: Implications for Risk Assessment. J. Food Prot. 2004, 67, 1201-1208. [CrossRef]

69. Oscar, T.P. General Regression Neural Network and Monte Carlo Simulation Model for Survival and Growth of Salmonella on Raw Chicken Skin as a Function of Serotype, Temperature, and Time for Use in Risk Assessment. J. Food Prot. 2009, 72, 2078-2087. [CrossRef] [PubMed]

70. Oscar, T.P. Neural network models for growth of Salmonella serotypes in ground chicken subjected to temperature abuse during cold storage for application in HACCP and risk assessment. Int. J. Food Sci. Technol. 2017, 52, 214-221. [CrossRef]

71. Ritz, M.; Nauta, M.J.; Teunis, P.F.M.; van Leusden, F.; Federighi, M.; Havelaar, A.H. Modelling of Campylobacter survival in frozen chicken meat. J. Appl. Microbiol. 2007, 103, 594-600. [CrossRef] [PubMed]

72. Sommers, C.; Huang, C.-Y.; Sheen, L.-Y.; Sheen, S.; Huang, L. Growth modeling of Uropathogenic Escherichia coli in ground chicken meat. Food Control 2018, 86, 397-402. [CrossRef]

73. Takhar, P.S.; Head, K.L.; Hendrix, K.M.; Smith, D.M. Predictive Modeling of Salmonella Species Inactivation in Ground Pork and Turkey during Cooking. Int. J. Food Eng. 2009, 5. [CrossRef]

74. Xiao, X.; Wang, W.; Zhang, J.; Liao, M.; Yang, H.; Fang, W.; Li, Y. Modeling the Reduction and Cross-Contamination of Salmonella in Poultry Chilling Process in China. Microorganisms 2019, 7, 448. [CrossRef]

75. Xiao, X.; Wang, W.; Zhang, X.; Zhang, J.; Liao, M.; Yang, H.; Zhang, Q.; Rainwater, C.; Li, Y. Modeling the Reduction of Salmonella spp. on Chicken Breasts and Wingettes during Scalding for QMRA of the Poultry Supply Chain in China. Microorganisms 2019, 7, 165. [CrossRef]

76. Marcotte, M.; Chen, C.R.; Grabowski, S.; Ramaswamy, H.S.; Piette, J.-P.G. Modelling of cooking-cooling processes for meat and poultry products. Int. J. Food Sci. Technol. 2008, 43, 673-684. [CrossRef] 
77. Ahmed, M.F.E.M.; El-Adawy, H.; Hotzel, H.; Tomaso, H.; Neubauer, H.; Kemper, N.; Hartung, J.; Hafez, H.M. Prevalence, genotyping and risk factors of thermophilic Campylobacter spreading in organic turkey farms in Germany. Gut Pathog. 2016, 8, 28. [CrossRef]

78. Allain, V.; Chemaly, M.; Laisney, M.-J.; Rouxel, S.; Quesne, S.; Le Bouquin, S. Prevalence of and risk factors for Campylobacter colonisation in broiler flocks at the end of the rearing period in France. Br. Poult. Sci. 2014, 55, 452-459. [CrossRef]

79. Ansari-Lari, M.; Hosseinzadeh, S.; Shekarforoush, S.S.; Abdollahi, M.; Berizi, E. Prevalence and risk factors associated with campylobacter infections in broiler flocks in Shiraz, southern Iran. Int. J. Food Microbiol. 2011, 144, 475-479. [CrossRef] [PubMed]

80. Arsenault, J.; Letellier, A.; Quessy, S.; Morin, J.-P.; Boulianne, M. Prevalence and Risk Factors for Salmonella and Campylobacter spp. Carcass Contamination in Turkeys Slaughtered in Quebec, Canada. J. Food Prot. 2007, 70, 1350-1359. [CrossRef] [PubMed]

81. Arsenault, J.; Letellier, A.; Quessy, S.; Boulianne, M. Prevalence and Risk Factors for Salmonella and Campylobacter spp. Carcass Contamination in Broiler Chickens Slaughtered in Quebec, Canada. J. Food Prot. 2007, 70, 1820-1828. [CrossRef] [PubMed]

82. Arsenault, J.; Letellier, A.; Quessy, S.; Normand, V.; Boulianne, M. Prevalence and risk factors for Salmonella spp. and Campylobacter spp. caecal colonization in broiler chicken and turkey flocks slaughtered in Quebec, Canada. Prev. Vet. Med. 2007, 81, 250-264. [CrossRef] [PubMed]

83. Aury, K.; Chemaly, M.; Petetin, I.; Rouxel, S.; Picherot, M.; Michel, V.; Le Bouquin, S. Prevalence and risk factors for Salmonella enterica subsp. enterica contamination in French breeding and fattening turkey flocks at the end of the rearing period. Prev. Vet. Med. 2010, 94, 84-93. [CrossRef]

84. Carron, M.; Chang, Y.-M.; Momanyi, K.; Akoko, J.; Kiiru, J.; Bettridge, J.; Chaloner, G.; Rushton, J.; O’Brien, S.; Williams, N.; et al. Campylobacter, a zoonotic pathogen of global importance: Prevalence and risk factors in the fast-evolving chicken meat system of Nairobi, Kenya. PLoS Negl. Trop. Dis. 2018, 12, e0006658. [CrossRef]

85. Djeffal, S.; Mamache, B.; Elgroud, R.; Hireche, S.; Bouaziz, O. Prevalence and risk factors for Salmonella spp. contamination in broiler chicken farms and slaughterhouses in the northeast of Algeria. Vet. World 2018, 11, 1102-1108. [CrossRef]

86. Dubey, J.P.; Hill, D.E.; Jones, J.L.; Hightower, A.W.; Kirkland, E.; Roberts, J.M.; Marcet, P.L.; Lehmann, T.; Vianna, M.C.B.; Miska, K.; et al. Prevalence of viable toxoplasma gondii in beef, chicken, and pork from retail meat stores in the united states: Risk assessment to consumers. J. Parasitol. 2005, 91, 1082-1093. [CrossRef]

87. El Allaoui, A.; Rhazi Filali, F.; Ameur, N.; Bouchrif, B. Contamination of broiler turkey farms by Salmonella spp. in Morocco: Prevalence, antimicrobial resistance and associated risk factors. Rev. Sci. Tech. OIE 2017, 36, 935-946. [CrossRef]

88. Habib, I.; Sampers, I.; Uyttendaele, M.; De Zutter, L.; Berkvens, D. A Bayesian modelling framework to estimate Campylobacter prevalence and culture methods sensitivity: Application to a chicken meat survey in Belgium. J. Appl. Microbiol. 2008, 105, 2002-2008. [CrossRef]

89. Henry, I.; Reichardt, J.; Denis, M.; Cardinale, E. Prevalence and risk factors for Campylobacter spp. in chicken broiler flocks in Reunion Island (Indian Ocean). Prev. Vet. Med. 2011, 100, 64-70. [CrossRef]

90. Hosseinzadeh, S.; Shekarforoush, S.S.; Ansari-Lari, M.; EsalatPanah-Fard Jahromi, M.; Berizi, E.; Abdollahi, M. Prevalence and Risk Factors for Listeria monocytogenes in Broiler Flocks in Shiraz, Southern Iran. Foodborne Pathog. Dis. 2012, 9, 568-572. [CrossRef]

91. Hue, O.; Le Bouquin, S.; Laisney, M.-J.; Allain, V.; Lalande, F.; Petetin, I.; Rouxel, S.; Quesne, S.; Gloaguen, P.-Y.; Picherot, M.; et al. Prevalence of and risk factors for Campylobacter spp. contamination of broiler chicken carcasses at the slaughterhouse. Food Microbiol. 2010, 27, 992-999. [CrossRef] [PubMed]

92. Hue, O.; Le Bouquin, S.; Lalande, F.; Allain, V.; Rouxel, S.; Petetin, I.; Quesne, S.; Laisney, M.-J.; Gloaguen, P.-Y.; Picherot, M.; et al. Prevalence of Salmonella spp. on broiler chicken carcasses and risk factors at the slaughterhouse in France in 2008. Food Control 2011, 22, 1158-1164. [CrossRef]

93. Ibrahim, M.J.; Abdul-Aziz, S.; Bitrus, A.A.; Mohammed, D.G.; Abu, J.; Bejo, S.K.; Mohamed, M.A.; Mohamed, M.Y.I. Occurrence of Multidrug resistant (MDR) Campylobacter species isolated from retail Chicken meats in Selangor, Malaysia and their associated risk factors. Malays. J. Microbiol. 2018. [CrossRef]

94. Kapperud, G.; Skjerve, E.; Vik, L.; Hauge, K.; Lysaker, A.; Aalmen, I.; Ostroff, S.M.; Potter, M. Epidemiological investigation of risk factors for Campylobacter colonization in Norwegian broiler flocks. Epidemiol. Infect. 1993, 111, 245-256. [CrossRef] [PubMed] 
95. Keeratipibul, S.; Lekroengsin, S. Risk Assessment of Listeria spp. Contamination in the Production Line of Ready-to-Eat Chicken Meat Products. J. Food Prot. 2008, 71, 946-952. [CrossRef] [PubMed]

96. Keeratipibul, S.; Meethong, S.; Techaruwichit, P.; Thephuttee, N. Prevalence of Escherichia coli and enterococci in a Thai frozen cooked chicken plant, and modeling of the cleaning and sanitizing procedure. Food Control 2010, 21, 1104-1112. [CrossRef]

97. Lawes, J.R.; Vidal, A.; Clifton-Hadley, F.A.; Sayers, R.; Rodgers, J.; Snow, L.; Evans, S.J.; Powell, L.F. Investigation of prevalence and risk factors for Campylobacter in broiler flocks at slaughter: Results from a UK survey. Epidemiol. Infect. 2012, 140, 1725-1737. [CrossRef]

98. Le Bouquin, S.; Allain, V.; Rouxel, S.; Petetin, I.; Picherot, M.; Michel, V.; Chemaly, M. Prevalence and risk factors for Salmonella spp. contamination in French broiler-chicken flocks at the end of the rearing period. Prev. Vet. Med. 2010, 97, 245-251. [CrossRef]

99. Mamber, S.W.; Mohr, T.; Leathers, C.; Mbandi, E.; Bronstein, P.; Barlow, K. Occurrence of Salmonella in Ready-to-Eat Meat and Poultry Product Samples from U.S. Department of Agriculture-Regulated Producing Establishments. I. Results from the ALLRTE and RTE001 Random and Risk-Based Sampling Projects, from 2005 to 2012. J. Food Prot. 2018, 81, 1729-1736. [CrossRef] [PubMed]

100. Mo, S.S.; Urdahl, A.M.; Nesse, L.L.; Slettemeås, J.S.; Ramstad, S.N.; Torp, M.; Norström, M. Occurrence of and risk factors for extended-spectrum cephalosporin-resistant Enterobacteriaceae determined by sampling of all Norwegian broiler flocks during a six month period. PLoS ONE 2019, 14, e0223074. [CrossRef] [PubMed]

101. Mulders, M.N.; Haenen, A.P.J.; Geenen, P.L.; Vesseur, P.C.; Poldervaart, E.S.; Bosch, T.; Huijsdens, X.W.; Hengeveld, P.D.; Dam-Deisz, W.D.C.; Graat, E.A.M.; et al. Prevalence of livestock-associated MRSA in broiler flocks and risk factors for slaughterhouse personnel in The Netherlands. Epidemiol. Infect. 2010, 138, 743-755. [CrossRef] [PubMed]

102. Osimani, A.; Aquilanti, L.; Pasquini, M.; Clementi, F. Prevalence and risk factors for thermotolerant species of Campylobacter in poultry meat at retail in Europe. Poult. Sci. 2017, 96, 3382-3391. [CrossRef]

103. Powell, L.F.; Lawes, J.R.; Clifton-Hadley, F.A.; Rodgers, J.; Harris, K.; Evans, S.J.; Vidal, A. The prevalence of Campylobacter spp. in broiler flocks and on broiler carcases, and the risks associated with highly contaminated carcases. Epidemiol. Infect. 2012, 140, 2233-2246. [CrossRef]

104. Rajan, K.; Shi, Z.; Ricke, S.C. Current aspects of Salmonella contamination in the US poultry production chain and the potential application of risk strategies in understanding emerging hazards. Crit. Rev. Microbiol. 2017, 43, 370-392. [CrossRef]

105. Rong, G.; Zhou, H.-L.; Hou, G.-Y.; Zhao, J.-M.; Xu, T.-S.; Guan, S. Seroprevalence, risk factors and genotyping of Toxoplasma gondii in domestic geese (Anser domestica) in tropical China. Parasit. Vectors 2014, 7, 459. [CrossRef]

106. Sevilla-Navarro, S.; Marin, C.; Cortés, V.; García, C.; Catalá-Gregori, P. Campylobacter prevalence and risk factors associated with exceeding allowable limits in poultry slaughterhouses in Spain. Vet. Rec. 2020, 186, vetrec-2019-105558. [CrossRef]

107. Torralbo, A.; Borge, C.; Allepuz, A.; García-Bocanegra, I.; Sheppard, S.K.; Perea, A.; Carbonero, A. Prevalence and risk factors of Campylobacter infection in broiler flocks from southern Spain. Prev. Vet. Med. 2014, 114, 106-113. [CrossRef]

108. Aliyu, A.B.; Saleha, A.A.; Jalila, A.; Zunita, Z. Risk factors and spatial distribution of extended spectrum $\beta$-lactamase-producing- Escherichia coli at retail poultry meat markets in Malaysia: A cross-sectional study. BMC Public Health 2016, 16, 699. [CrossRef]

109. Aury, K.; Le Bouquin, S.; Toquin, M.-T.; Huneau-Salaün, A.; Le Nôtre, Y.; Allain, V.; Petetin, I.; Fravalo, P.; Chemaly, M. Risk factors for Listeria monocytogenes contamination in French laying hens and broiler flocks. Prev. Vet. Med. 2011, 98, 271-278. [CrossRef] [PubMed]

110. Avrain, L.; Humbert, F.; L'Hospitalier, R.; Sanders, P.; Kempf, I. Antimicrobial resistance in Campylobacter from broilers. Br. Poult. Sci. 2001, 42, 32-43. [CrossRef]

111. Barrios, P.R.; Reiersen, J.; Lowman, R.; Bisaillon, J.-R.; Michel, P.; Fridriksdóttir, V.; Gunnarsson, E.; Stern, N.; Berke, O.; McEwen, S.; et al. Risk factors for Campylobacter spp. colonization in broiler flocks in Iceland. Prev. Vet. Med. 2006, 74, 264-278. [CrossRef] [PubMed]

112. Borck Høg, B.; Sommer, H.M.; Larsen, L.S.; Sørensen, A.I.V.; David, B.; Hofshagen, M.; Rosenquist, H. Farm specific risk factors for Campylobacter colonisation in Danish and Norwegian broilers. Prev. Vet. Med. 2016, 130, 137-145. [CrossRef] 
113. Bouwknegt, M.; van de Giessen, A.W.; Dam-Deisz, W.D.C.; Havelaar, A.H.; Nagelkerke, N.J.D.; Henken, A.M. Risk factors for the presence of Campylobacter spp. in Dutch broiler flocks. Prev. Vet. Med. 2004, 62, 35-49. [CrossRef]

114. Bryan, F.L.; Doyle, M.P. Health Risks and Consequences of Salmonella and Campylobacter jejuni in Raw Poultry. J. Food Prot. 1995, 58, 326-344. [CrossRef]

115. Cardinale, E.; Tall, F.; Guèye, E.F.; Cisse, M.; Salvat, G. Risk factors for Campylobacter spp. infection in Senegalese broiler-chicken flocks. Prev. Vet. Med. 2004, 64, 15-25. [CrossRef]

116. Cardinale, E.; Tall, F.; Cissé, M.; Guèye, E.F.; Salvat, G.; Mead, G. Risk factors associated with Salmonella enterica subsp. enterica contamination of chicken carcases in Senegal. Br. Poult. Sci. 2005, 46, 293-299. [CrossRef]

117. Cardinale, E.; Perrier Gros-Claude, J.D.; Tall, F.; Guèye, E.F.; Salvat, G. Risk factors for contamination of ready-to-eat street-vended poultry dishes in Dakar, Senegal. Int. J. Food Microbiol. 2005, 103, 157-165. [CrossRef]

118. Carson, C.; Li, X.-Z.; Agunos, A.; Loest, D.; Chapman, B.; Finley, R.; Mehrotra, M.; Sherk, L.M.; Gaumond, R.; Irwin, R. Ceftiofur-resistant Salmonella enterica serovar Heidelberg of poultry origin-A risk profile using the Codex framework. Epidemiol. Infect. 2019, 147, e296. [CrossRef]

119. Chaves, R.D.; Silva, A.R.; Alvarenga, V.O.; Pereira, J.L.; Mousavi Khaneghah, A. The modeling of time to enterotoxin detection of Staphylococcus aureus in chicken meat. J. Food Saf. 2017, 37, e12342. [CrossRef]

120. Chowdhury, S.; Sandberg, M.; Themudo, G.E.; Ersbøll, A.K. Risk factors for Campylobacter infection in Danish broiler chickens. Poult. Sci. 2012, 91, 2701-2709. [CrossRef] [PubMed]

121. Chutia, R. Fuzzy risk analysis using similarity measure of interval-valued fuzzy numbers and its application in poultry farming. Appl. Intell. 2018, 48, 3928-3949. [CrossRef]

122. Cufaoglu, G.; Ayaz, N.D. Listeria monocytogenes risk associated with chicken at slaughter and biocontrol with three new bacteriophages. J. Food Saf. 2019, 39, e12621. [CrossRef]

123. Ellis-Iversen, J.; Jorgensen, F.; Bull, S.; Powell, L.; Cook, A.J.; Humphrey, T.J. Risk factors for Campylobacter colonisation during rearing of broiler flocks in Great Britain. Prev. Vet. Med. 2009, 89, 178-184. [CrossRef]

124. Featherstone, C.A.; Reichel, R.; Snow, L.C.; Davies, R.H.; Christiansen, K.H.; Carrique-Mas, J.J.; Evans, S.J. Investigation of risk factors for Salmonella on fattening-turkey farms. Epidemiol. Infect. 2010, 138, 1427-1438. [CrossRef]

125. Guerin, M.T.; Martin, S.W.; Reiersen, J.; Berke, O.; McEwen, S.A.; Friðriksdóttir, V.; Bisaillon, J.-R.; Lowman, R. Temperature-related risk factors associated with the colonization of broiler-chicken flocks with Campylobacter spp. in Iceland, 2001-2004. Prev. Vet. Med. 2008, 86, 14-29. [CrossRef]

126. Guerin, M.T.; Martin, W.; Reiersen, J.; Berke, O.; McEwen, S.A.; Bisaillon, J.-R.; Lowman, R. House-level risk factors associated with the colonization of broiler flocks with Campylobacter spp. in Iceland, 2001-2004. BMC Vet. Res. 2007, 3, 30. [CrossRef]

127. Hansson, I.; Engvall, E.O.; Vågsholm, I.; Nyman, A. Risk factors associated with the presence of Campylobacter-positive broiler flocks in Sweden. Prev. Vet. Med. 2010, 96, 114-121. [CrossRef]

128. Huneau-Salaün, A.; Denis, M.; Balaine, L.; Salvat, G. Risk factors for Campylobacter spp. colonization in French free-range broiler-chicken flocks at the end of the indoor rearing period. Prev. Vet. Med. 2007, 80, 34-48. [CrossRef]

129. Kuana, S.; Santos, L.; Rodrigues, L.; Borsoi, A.; Moraes, H.; Salle, C.; Nascimento, V. Risk factors and likelihood of Campylobacter colonization in broiler flocks. Rev. Bras. Ciênc. Avícola 2007, 9, 201-204. [CrossRef]

130. Lyngstad, T.M.; Jonsson, M.E.; Hofshagen, M.; Heier, B.T. Risk Factors Associated with the Presence of Campylobacter Species in Norwegian Broiler Flocks. Poult. Sci. 2008, 87, 1987-1994. [CrossRef] [PubMed]

131. Marin, C.; Hernandiz, A.; Lainez, M. Biofilm development capacity of Salmonella strains isolated in poultry risk factors and their resistance against disinfectants. Poult. Sci. 2009, 88, 424-431. [CrossRef] [PubMed]

132. Mataragas, M.; Skandamis, P.; Drosinos, E. Risk profiles of pork and poultry meat and risk ratings of various pathogen/product combinations. Int. J. Food Microbiol. 2008, 126, 1-12. [CrossRef] [PubMed]

133. McDowell, S.W.J.; Menzies, F.D.; McBride, S.H.; Oza, A.N.; McKenna, J.P.; Gordon, A.W.; Neill, S.D. Campylobacter spp. in conventional broiler flocks in Northern Ireland: Epidemiology and risk factors. Prev. Vet. Med. 2008, 84, 261-276. [CrossRef] [PubMed] 
134. Mezali, L.; Mebkhout, F.; Nouichi, S.; Boudjellaba, S.; Hamdi, T.-M. Serotype diversity and slaughterhouse-level risk factors related to Salmonella contamination on poultry carcasses in Algiers. J. Infect. Dev. Ctries. 2019, 13, 384-393. [CrossRef]

135. Milanov, D.; Ljubojević, D.; Čabarkapa, I.; Karabasil, N.; Velhner, M. Biofilm as risk factor for Salmonella contamination in various stages of poultry production. Poult. Sci. 2017, 81. [CrossRef]

136. Mo, S.S.; Kristoffersen, A.B.; Sunde, M.; Nødtvedt, A.; Norström, M. Risk factors for occurrence of cephalosporin-resistant Escherichia coli in Norwegian broiler flocks. Prev. Vet. Med. 2016, 130, 112-118. [CrossRef]

137. Näther, G.; Alter, T.; Martin, A.; Ellerbroek, L. Analysis of risk factors for Campylobacter species infection in broiler flocks. Poult. Sci. 2009, 88, 1299-1305. [CrossRef]

138. Pieskus, J.; Butrimaite-Ambrazeviciene, C.; Kazeniauskas, E.; Stanevicius, Z.; Mauricas, M. Risk factors for the presence of Campylobacter sp. in Lithuanian broiler flocks. Int. J. Poult. Sci. 2008, 7, 1242-1246. [CrossRef]

139. Refrégier-Petton, J.; Rose, N.; Denis, M.; Salvat, G. Risk factors for Campylobacter spp. contamination in French broiler-chicken flocks at the end of the rearing period. Prev. Vet. Med. 2001, 50, 89-100. [CrossRef]

140. Rivera-Pérez, W.; Barquero-Calvo, E.; Zamora-Sanabria, R. Salmonella Contamination Risk Points in Broiler Carcasses during Slaughter Line Processing. J. Food Prot. 2014, 77, 2031-2034. [CrossRef] [PubMed]

141. Rose, N.; Beaudeau, F.; Drouin, P.; Toux, J.Y.; Rose, V.; Colin, P. Risk factors for Salmonella enterica subsp. enterica contamination in French broiler-chicken flocks at the end of the rearing period. Prev. Vet. Med. 1999, 39, 265-277. [CrossRef]

142. Rushton, S.P.; Humphrey, T.J.; Shirley, M.D.F.; Bull, S.; Jørgensen, F. Campylobacter in housed broiler chickens: A longitudinal study of risk factors. Epidemiol. Infect. 2009, 137, 1099-1110. [CrossRef] [PubMed]

143. Sarr, A.; Galal, L.; Boumediene, F.; Hamidović, A.; Dardé, M.-L.; Diallo, M.; Sow, A.; Niang, Y.; Cuny, T.; Mercier, A. Seroprevalence and Risk Factors of Toxoplasma gondii Infection in Free-Range Chickens in Senegal, West Africa. Vector-Borne Zoonotic Dis. 2020, 20, 15-21. [CrossRef]

144. Sasaki, Y.; Tsujiyama, Y.; Tanaka, H.; Yoshida, S.; Goshima, T.; Oshima, K.; Katayama, S.; Yamada, Y. Risk Factors for Campylobacter Colonization in Broiler Flocks in Japan: Campylobacter in Broiler Farms in Japan. Zoonoses Public Health 2011, 58, 350-356. [CrossRef]

145. Schaumburg, F.; Alabi, A.S.; Frielinghaus, L.; Grobusch, M.P.; Köck, R.; Becker, K.; Issifou, S.; Kremsner, P.G.; Peters, G.; Mellmann, A. The risk to import ESBL-producing Enterobacteriaceae and Staphylococcus aureus through chicken meat trade in Gabon. BMC Microbiol. 2014, 14, 286. [CrossRef]

146. Sommer, H.M.; Nauta, M.J.; Rosenquist, H. Translation of risk factor estimates into on-farm interventions and their effect on Campylobacter broiler flock prevalence. Microb. Risk Anal. 2016, 2, 27-37. [CrossRef]

147. Sommer, H.M.; Høg, B.B.; Larsen, L.S.; Sørensen, A.I.V.; Williams, N.; Merga, J.Y.; Cerdà-Cuéllar, M.; Urdaneta, S.; Dolz, R.; Wieczorek, K.; et al. Analysis of farm specific risk factors for Campylobacter colonization of broilers in six European countries. Microb. Risk Anal. 2016, 2, 16-26. [CrossRef]

148. Munther, D.; Sun, X.; Xiao, Y.; Tang, S.; Shimozako, H.; Wu, J.; Smith, B.A.; Fazil, A. Modeling cross-contamination during poultry processing: Dynamics in the chiller tank. Food Control 2016, 59, 271-281. [CrossRef]

149. Possas, A.M.M.; Posada-Izquierdo, G.D.; Pérez-Rodríguez, F.; García-Gimeno, R.M. Modeling the Transfer of Salmonella Enteritidis during Slicing of Ready-to-Eat Turkey Products Treated with Thyme Essential Oil. J. Food Sci. 2016, 81, M2770-M2775. [CrossRef] [PubMed]

150. Cumhur, Ö.; Şeker, M.; Sadıkoğlu, H. Freeze drying of turkey breast meat: Mathematical modeling and estimation of transport parameters. Dry. Technol. 2016, 34, 584-594. [CrossRef]

151. Rabeler, F.; Feyissa, A.H. Modelling of food processes under uncertainty: Mechanistic 3D model of chicken meat roasting. J. Food Eng. 2019, 262, 49-59. [CrossRef]

152. Horne, P.L.M.; van Bondt, N. Competitiveness of the EU Poultry Meat Sector; The Hague: Wageningen, The Netherlands, 2013; ISBN 978-90-8615-664-1.

153. de Swarte, C.; Donker, R.A. Towards an FSO/ALOP based food safety policy. Food Control 2005, 16, 825-830. [CrossRef] 
154. Worsfold, D.; Griffith, C.J. Assessment of the Standard of Consumer Food Safety Behavior. J. Food Prot. 1997, 60, 399-406. [CrossRef]

155. Williamson, D.M.; Gravani, R.B.; Lawless, H.T. Correlating food safety knowledge with home food-preparation practices. Food Technol. USA 1992, 46, 94-100.

156. Yoon, K.S.; Burnette, C.N.; Oscar, T.P. Development of Predictive Models for the Survival of Campylobacter jejuni (ATCC 43051) on Cooked Chicken Breast Patties and in Broth as a Function of Temperature. J. Food Prot. 2004, 67, 64-70. [CrossRef]

157. Solow, B.T.; Cloak, O.M.; Fratamico, P.M. Effect of Temperature on Viability of Campylobacter jejuni and Campylobacter coli on Raw Chicken or Pork Skin. J. Food Prot. 2003, 66, 2023-2031. [CrossRef]

158. Chan, K.F.; Tran, H.L.; Kanenaka, R.Y.; Kathariou, S. Survival of Clinical and Poultry-Derived Isolates of Campylobacter jejuni at a Low Temperature $\left(4^{\circ} \mathrm{C}\right)$. Appl. Environ. Microbiol. 2001, 67, 4186-4191. [CrossRef]

159. Bhaduri, S.; Cottrell, B. Survival of Cold-Stressed Campylobacter jejuni on Ground Chicken and Chicken Skin during Frozen Storage. Appl. Environ. Microbiol. 2004, 70, 7103-7109. [CrossRef]

160. Hänninen, M.L. Survival of Campylobacter jejuni/coli in ground refrigerated and in ground frozen beef liver and in frozen broiler carcasses. Acta Vet. Scand. 1981, 22, 566-577. [PubMed]

161. Birk, T.; Rosenquist, H.; Brøndsted, L.; Ingmer, H.; Bysted, A.; Christensen, B.B. A Comparative Study of Two Food Model Systems to Test the Survival of Campylobacter jejuni at $-18{ }^{\circ}$ C. J. Food Prot. 2006, 69, 2635-2639. [CrossRef] [PubMed]

162. Sandberg, M.; Hofshagen, M.; Østensvik, Ø.; Skjerve, E.; Innocent, G. Survival of Campylobacter on Frozen Broiler Carcasses as a Function of Time. J. Food Prot. 2005, 68, 1600-1605. [CrossRef]

163. Georgsson, F.; Porkelsson, Á.E.; Geirsdóttir, M.; Reiersen, J.; Stern, N.J. The influence of freezing and duration of storage on Campylobacter and indicator bacteria in broiler carcasses. Food Microbiol. 2006, 23, 677-683. [CrossRef] [PubMed]

164. Murphy, R.; Duncan, L.; Berrang, M.; Marcy, J.; Wolfe, R. Thermal inactivation D- and Z-values of Salmonella and Listeria innocua in fully cooked and vacuum packaged chicken breast meat during postcook heat treatment. Poult. Sci. 2002, 81, 1578-1583. [CrossRef] [PubMed]

165. Food and Agriculture Organization of the United Nations/World Health Organization. Risk Assessments of "Salmonella" in Eggs and Broiler Chickens; World Health Organization Food and Agriculture Organization of the United Nations: Geneva, Switzerland, 2002; ISBN 978-92-9156-229-9.

166. The International Commission on Microbiological Specifications for Foods. Microorganisms in Foods 5: Characteristics of Microbial Pathogens; Springer Science \& Business Media: Berlin, Germany, 1996; ISBN 978-0-412-47350-0.

167. Joint FAO/WHO. Expert Consultation on Risk Assessment of Microbiological Hazards in Foods W. H. O. Food Safety Programme Food, Agriculture Organization of the United, Nations. Joint FAO/WHO Expert Consultation on Risk Assessment of Microbiological Hazards in Foods: Hazard Identification, Exposure Assessment and Hazard Characterization of Campylobacter spp. in Broiler Chickens and Vibrio spp. in Seafood, WHO Headquarters, Geneva, Switzerland, 23-27 July 2001. World Health Organization. Available online: https://apps.who.int/iris/handle/10665/67090 (accessed on 2 November 2020).

168. Joint FAO/WHO Expert Meetings on Microbiological Risk Assessment (JEMRA) on Methodologies of Microbiological Risk Assessment FAO/WHO Public Consultation for Draft Guidance of Microbiological Risk Assessment for Food. Available online: https://www.who.int/news-room/articles-detail/public-consultationfor-draft-guidance-of-microbiological-risk-assessment-for-food (accessed on 2 November 2020).

169. Henley, S.C. "Don't Wash Your Chicken!" Results of an Interdisciplinary Approach to Reduce Incidence of Infectious Foodborne Diseases; Drexel University: Philadelphia, PA, USA, 2013.

170. Bamgboje-Ayodele, A.; Ellis, L.; Turner, P. Developing a Framework for Understanding and Enhancing Consumers' Safe Food Management Behaviors-A Literature Review. J. Agric. Food Inf. 2019, 20, 315-343. [CrossRef]

171. Young, I.; Waddell, L.; Harding, S.; Greig, J.; Mascarenhas, M.; Sivaramalingam, B.; Pham, M.T.; Papadopoulos, A. A systematic review and meta-analysis of the effectiveness of food safety education interventions for consumers in developed countries. BMC Public Health 2015, 15. [CrossRef] 
172. Lee-Kwan, S.H.; DeLuca, N.; Bunnell, R.; Clayton, H.B.; Turay, A.S.; Mansaray, Y. Facilitators and Barriers to Community Acceptance of Safe, Dignified Medical Burials in the Context of an Ebola Epidemic, Sierra Leone, 2014. J. Health Commun. 2017, 22, 24-30. [CrossRef]

173. Szaszi, B.; Palinkas, A.; Palfi, B.; Szollosi, A.; Aczel, B. A Systematic Scoping Review of the Choice Architecture Movement: Toward Understanding When and Why Nudges Work. J. Behav. Decis. Mak. 2018, 31, 355-366. [CrossRef]

Publisher's Note: MDPI stays neutral with regard to jurisdictional claims in published maps and institutional affiliations.

(C) 2020 by the authors. Licensee MDPI, Basel, Switzerland. This article is an open access article distributed under the terms and conditions of the Creative Commons Attribution (CC BY) license (http://creativecommons.org/licenses/by/4.0/). 